\title{
Spatial heterogeneity of macrofaunal communities in and near a giant pockmark area in the deep Gulf of Guinea
}

\author{
Lénaïck Menot ${ }^{1,2,{ }^{*}}$, Joëlle Galéron ${ }^{2}$, Karine Olu ${ }^{2}$, Jean-Claude Caprais ${ }^{2}$, Philippe Crassous $^{2}$, \\ Alexis Khripounoff ${ }^{2}$ \& Myriam Sibuet ${ }^{1}$
}

${ }^{1}$ Institut Océanographique, Rue Saint Jacques, Paris, France

${ }^{2}$ Ifremer, Département DEEP/LEP, Centre de Brest, Plouzané, France

*: Corresponding author : L. Menot, email address : Lenaick.Menot@ifremer.fr

\begin{abstract}
:
The structure and familial-level composition of macrofaunal communities were examined within and at distance from the giant pockmark Regab in the Southern Gulf of Guinea, at 3200 m depth. The two main questions addressed in this study were (i) does habitat partitioning by large symbiont-bearing taxa influence macrofaunal assemblages and their environment? and (ii) to what extent does the chemosynthesis-based ecosystem influence the structure and the composition of nearby macrobenthic communities? Along two radials, at sites from 250 to $1000 \mathrm{~m}$ away from the active centre of the cold seep, the abundance and composition of the macrofauna were typical of a deep-sea community at that depth. Except for a few cores sampled in or near dead vesicomyid fields at the border of the pockmark area, the chemosynthetic ecosystem had no significant influence on macrofaunal communities beyond the edge of the giant pockmark. In seep sediments, the macrofauna had higher densities, reaching over 22,000 ind.m-2, but lower taxonomic richness than in background sediments. The polychaete assemblages associated with siboglinid tubeworms differed in their composition and vertical distribution from communities associated with vesicomyids or found at the border between vesicomyids and mytilids. The siboglinid habitat was dominated by surface-feeders (ampharetids) or small carnivores (dorvilleids, hesionids and syllids) concentrated in the top sediment layer, while the vesicomyid beds were dominated by deep-dwelling, subsurface feeders (capitellids and cossurids). This pattern may be related to bioturbation by the vesicomyids that allows an oxygenation of surface sediments while deepening down and enhancing the anaerobic oxidation of methane. Although alpha diversity of polychaete families is low in seep sediments, the variability of faunal assemblages and potentially high level of speciation in cold-seep environments point to high beta diversity. Comparable numbers of polychaete families coexist in a quarter square meter of seep or non-seep sediments, although the number of ecological niches that were sampled might be higher at seeps. Further integrative and comparative studies of the diversity and functioning of seep and non-seep communities would certainly provide clues to understanding both ecosystems and their interactions.
\end{abstract}

Keywords: Cold seep $\bullet$ diversity $\bullet$ Gulf of Guinea $\bullet$ habitat heterogeneity $\bullet$ macrofauna $\bullet$ open slope $\bullet$ siboglinid tubeworms $\bullet$ vesicomyid clams 


\section{Introduction}

Along vast portions of sedimentary slopes, in a seemingly never-ending muddy landscape, where habitat partitioning is mainly out of sight and ephemeral (Jumars 1975; Menot et al. 2009), cold-seep ecosystems contrast in offering a patchwork of substrates, oxic/anoxic sediments and microbial/megafaunal assemblages Novel habitats are created by dense assemblages of dominant symbiont-bearing taxa or chemosynthetic bacterial mats. The chemosynthetic megafauna mainly belong to families of bivalves (e.g. Mytilidae, Vesicomyidae, Solemyidae, Lucinidae) and of polychaetes (Siboglinidae), whose distribution patterns within a seep are governed by fluid flow patterns (Sibuet \& Olu 1998; Sibuet \& OluLe Roy 2002). Each of these taxa present particular morphological, behavioural and symbiotic features such as siboglinid roots, deep sediment dwelling by vesicomyids or dual thio- and methanotrophic symbioses in mytilids. These taxon-specific features allow them to exploit particular niches according to fluid flow intensity, sulphide and methane concentrations or the vertical distribution of sulphides in sediments (Levin 2005). These symbiont-bearing species have been considered both as habitat indicators and habitat providers for the accompanying faunal assemblages through activities such as bioturbation and by creation of biogenic substrate. Among the epifauna living in mussel beds and siboglinid bushes many species are seep-endemic (Cordes et al. this volume), especially in the youngest communities characterizing highly active seepages (Bergquist, et al. 2003; Bergquist et al. 2005; Cordes et al. 2006). The influence of these 'ecosystem engineers' (sensu Levin 2005) on macrofaunal communities $(>0.3 \mathrm{~mm}$ ) also has been observed although the co-variations in structure and composition between megafauna and macrofauna are not as clear as for the epifauna (see Levin 2005 for a review). Schematically, along a gradient of fluid flow and concentration in sulphides, the two end members that are bacterial mats and non-seep sediments have different macrobenthic assemblages in terms of structure and composition (Levin 2005). The macrofaunal assemblages associated with vesicomyids or siboglinids however may either resemble those from background sediments (e.g. Hydrate Ridge: Sahling et al. 2002; Eel River: Levin et al. 2003; Florida Escarpment and Kodiak: Levin \& Mendoza 2007) or not (e.g. Northern California: Levin et al. 2000; Unimak: Levin \& Mendoza 2007). Species turnover or beta diversity associated with cold seeps may thus vary from high to null for the macrofauna. Similarly, alpha diversity can either be enhanced, constant or reduced in seep sediments compare to the open slope (Levin 2005). The relationship between habitat heterogeneity, as defined by megafaunal assemblages, and the diversity of the macrofauna thus is not straightforward in cold seep environments.

Here we examine the structure and composition of macrofaunal assemblages in and near one of the largest cold seep areas in the Atlantic Ocean. The so-called giant pockmark 
Regab is located north of the Congo canyon at $3160 \mathrm{~m}$ depth (Ondréas et al. 2005). Megafaunal communities are characterized by a mosaic of dense assemblages either dominated by siboglinid tube-worms, mytilids or vesicomyids, whose spatial patterns were related to methane concentrations in seawater and substratum (Olu-Le Roy et al. 2007). The juxtaposition of many patches of the three symbiont-bearing taxa suggested generally strong but highly variable fluid flow patterns. In the framework of the Biozaire programme (Sibuet \& Vangriesheim 2009), we studied the effects of habitat heterogeneity on the structure and composition of macrofaunal communities, with a focus on familial assemblages of polychaetes, at two spatial scales: i) within the giant pockmark, between putative habitats and ii) between the pockmark area and the surrounding open slope environment. Our main purpose was to assess the overall influence of the giant pockmark Regab on the diversity of macrobenthic communities. To do so, the main questions we addressed were:

1) Does habitat partitioning by large symbiont-bearing taxa influence macrofaunal assemblages and their environment?

2) To what extent does the chemosynthesis-based ecosystem influence the structure and the composition of nearby macrobenthic communities?

\section{Material and Methods}

\subsection{Study site}

The giant pockmark area called REGAB is located $8 \mathrm{~km}$ north of the Congo canyon, at 3160 $\mathrm{m}$ depth. The depression, $800 \mathrm{~m}$ wide and $15 \mathrm{~m}$ deep, is made of a series of pockmarks, each less than a $100 \mathrm{~m}$ in diameter, aligned along a SE - NW axis (Ondréas et al. 2005). Three main types of megafaunal assemblages, characterized by the dominance of siboglinid tubeworms (Figure 1A), mytilid mussels (Figure1B) or vesicomyid bivalves (Figure 1C), form a patchwork of habitats along this axis (Figure $2 \mathrm{~B}$ ). The central section is dominated by the siboglinids and mytilids, which may be found alone or in association with one another. The tubeworm Escarpia southwardae (Andersen et al. 2004) forms bushes of various sizes usually fixed on carbonate concretions. The mytilids, belonging to the Bathymodiolus aff. boomerang complex, are associated with the highest concentrations of methane (Olu-Le Roy et al. 2007). This species is characterized by a dual symbiosis with sulphide- and methaneoxidizing bacteria (Duperron et al. 2005). The vesicomyids in the central section of the pockmark form small and apparently monospecific clusters of Calyptogena regab, (Cosel \& Olu 2009), that are often found in reduced black sediments (Olu-Le Roy et al. 2007). The largest vesicomyid beds however are located in the periphery of the active area in depressions that may correspond to individual pockmarks (Ondréas et al. 2005). In these large beds, C. regab is found in association with Laubiericoncha chuni (Cosel \& Olu 2008). 
In this study, the distribution of the three symbiont-bearing taxa has been used to define habitats a priori and to conduct stratified macrofaunal sampling within the pockmark.

\subsection{Sampling design and methods}

Two different sampling designs were adopted according to the two spatial scales of interest:

- Within the pockmark, six sites were sampled during Biozaire1 and Biozaire2 cruises (Figure 2B):

- S1 and S2, near bushes of siboglinid tube worms;

- M3, near a cluster of mytilids;

- V1 and V2 at the periphery of living vesicomyid fields;

- O1, at the western inactive edge of Regab.

A detailed description of each site is given in Table 1 and images are shown on Figure 1.

Macrofauna was sampled using a blade corer $(C L)$, which is made of a rectangular box 20 $\mathrm{cm}$ long, $9 \mathrm{~cm}$ wide and $30 \mathrm{~cm}$ deep. The corer is gently pushed in sediments by the arm of the ROV and closed by two blades, armed by spiral springs and released by a quarter turn of the handle. The sediment for physico-chemical analyses was sampled using a push core (CT) $5.4 \mathrm{~cm}$ in diameter.

- Outside the pockmark, the largest sampling effort was done during the Biozaire 3 cruise (Galéron et al. 2009). Six sites were equally distributed along two radials north and south of the active area (Figure 2A). The sites R7, R9 and R10 were located north of Regab at $250 \mathrm{~m}$, $500 \mathrm{~m}$ and over $1000 \mathrm{~m}$ respectively from the active centre. The sites R6, R4 and R3 were located south of Regab, at similarly increasing distance from the pockmark. The site R7 differed from the others along the radials in that it was likely located in a patch of active seepage adjacent to a cluster of dead vesicomyids (Galéron et al. 2009). At each site, three USNEL box cores were sampled for the macrofauna and one multiple corer was deployed for physico-chemical analyses of the sediment. More information on these sites and how they compare with abyssal sites in the deep Gulf of Guinea can be found in Galéron et al. (2009). Two additional box cores were sampled during Biozaire2 at site $\mathrm{O} 2$ located at the eastern periphery of the active site.

All macrofaunal samples were sliced in four layers $(0-1 \mathrm{~cm}, 1-3 \mathrm{~cm}, 3-5 \mathrm{~cm}$ and $5-10 \mathrm{~cm})$ and each layer was sieved on a stack of four sieves of decreasing mesh size $(1 \mathrm{~mm}, 0.5 \mathrm{~mm}, 0.3$ $\mathrm{mm}$ and $0.25 \mathrm{~mm}$ ). The residues were fixed in $4 \%$ buffered formaldehyde and transferred in $70 \%$ alcohol within a few days. In the laboratory, all sub-samples (i.e. from each layer and sieve per sample) were stained with Rose Bengal. The macrofauna sensu stricto (i.e. excluding meiofaunal taxa, see Hessler \& Jumars 1974, Dinet et al. 1985) was sorted, counted and identified at the phylum down to order level. The polychaetes were later 
identified at the family level. This low taxonomic resolution may be an issue in the assessment of differences in community structure or diversity. Shallow water studies examining the effects of taxonomic resolution on patterns of spatial variation or taxonomic richness of macrobenthos usually show a strong correlation between results at familial and specific levels (e.g. James et al. 1995; Olsgard et al. 2003). In the deep sea, similar conclusions have also been drawn for the study of taxonomic richness in chemosynthetic communities (Doerries \& Van Dover, 2003). Pearson \& Rosenberg (1978) suggested a relationship between environmental stress and taxonomic variability whereby increasing environmental changes are manifest at decreasing taxonomic resolutions. Hence, some information may still be lost in lower range of environmental changes. This loss may be more acute in the deep sea, where polychaete families such as the Spionidae, Cirratulidae or Dorvilleidae are highly speciose (Blake \& Grassle 1994) and confamilial species may have dissimilar, sometimes antagonist, responses to environmental changes, such as the spionids (Narayanaswamy et al. 2003) or may have undergone major speciation in cold-seep environments such as the dorvilleids (Levin et al. 2006). Considering the apparent contrast between the habitats examined in this study, and the difficulty of accurate species identifications, we expected familial assemblages of polychaetes to be taxonomically sufficient. We cannot however, exclude the possibility that small variations in community structure might have been missed.

Two environmental parameters, oxygen and organic carbon content, were available for comparisons between sites inside and outside the pockmark. Sediment oxygen profiles were generated onboard ship using microelectrodes of Clark type (Unisense), with an outer tip diameter of 40 to $60 \mu \mathrm{m}$ and an internal reference in the overlying water. For the analysis of organic carbon content, the core was sliced every $0.5 \mathrm{~cm}$ in the first five centimetres, every 1 $\mathrm{cm}$ from 5 to $10 \mathrm{~cm}$ and every $2 \mathrm{~cm}$ below $10 \mathrm{~cm}$. The sediment samples were frozen onboard. In the laboratory, each sample was freeze dried. Organic carbon content was measured with a Leco WR12 auto-analyzer on an aliquot of crushed sediments after inorganic carbonate was removed by $2 \mathrm{~N} \mathrm{HCl}$.

\subsection{Statistical treatments}

Diversity patterns within and outside the pockmark area were assessed on familial assemblages of polychaetes. The Hurlbert's ES(n), Shannon-Wiener's H', Simpson's D and Pielou's J' indices were computed using Biodiversity Pro. Individual-based and samplebased rarefaction curves were generated using Ecosim software (Gotelli \& Entsminger 2009). 
Considering the low level of replication within sites inside the pockmark and differences in sampling strategies within and outside the pockmark area, data analyses mainly rely upon descriptive statistics. An exact Mann-Whitney $U$ test however, was performed in order to compare densities and taxonomic diversity within and outside the pockmark. Densities were normalised to one square meter prior to the analysis. Only the ES(n) measure of diversity was used for the test as this index is most suitable for non-standardized sample sizes (Soetaert \& Heip, 1990). Linear and non-linear regressions were used to test the influence of distance on macrobenthic densities and taxonomic diversity along the two radial transects from the active centre of the seep area. Both analyses were performed using the package Stats in R.

Variations in community composition among sites were analysed using clustering analysis and Principal Component Analysis. In both cases, the Hellinger distance was used to describe dissimilarities among sites. For the PCA, abundance data were transformed as described in Legendre and Gallagher (2001) in order to use the Hellinger distance among samples rather than the Euclidean distance, normally used in PCA. In the analysis of macrobenthic communities, the Hellinger distance offers several advantages over the Euclidean distance. In particular it gives a lower weight to dominant taxa and does not consider double absence as an indicator of similarity between samples (Legendre and Gallagher 2001).

Principal component analyses were performed using the software ADE-4 (Thioulouse, Chessel et al. 1997) and the statistical package Vegan for R (Oksanen, Kindt et al. 2008).

\section{Results}

\subsection{Environmental descriptors of habitats}

The organic carbon content and oxygen profiles in sediments were used to describe the environment at each site except S1, O1 and $\mathrm{O} 2$ where no data were available (Figure 3). These two parameters define a gradient of chemically-determined habitats. Along this gradient, most sites along the radial outside the pockmark, except R7, represent background non-seep environmental conditions where organic carbon concentration is low and oxygen penetration is deeper than $20 \mathrm{~mm}$. At the other end of the gradient, S2 and M3 exhibit the highest organic carbon content and thinnest oxic layer. In between, the two vesicomyid sites, V1 and V3, together with R7, have intermediate concentrations in organic carbon. These three later sites differ by their oxygen profiles, R7 being more oxygenated than $\mathrm{V} 1$ and $\mathrm{V} 3$ but still less oxygenated than the other sites along the radials outside the seep area. 


\subsection{Faunal descriptors of habitats}

Macrofaunal densities are in most cases higher within the pockmark than in background sediments (Table 2). The difference is not statistically significant when 01 , sampled at the NE edge of the pockmark, is listed among seep sites $(U=8, p=0.07)$. The difference however is statistically significant when $\mathrm{O} 1$ is removed from the analysis $(U=2, p=0.01)$.

Along the radials, at sites sampled with a box corer, densities range from 1720 to 2473 individuals per $\mathrm{m}^{2}$ except at $\mathrm{R} 7$ where densities are twice as high and similar to that found at O1. In fact, high densities at R7 are mainly due to one single box core, which contained empty shells of vesicomyids and a piece of carbonate, and thus likely sampled a bed of dead vesicomyids at the edge of the pockmark, very similar to the one observed at O1. Although macrofaunal densities are enhanced within the pockmark, beyond the edge of the site there is no relationship between density and distance along the radials (best model: logarithmic regression, $r^{2}=0.36, p=0.20$ ). Within the active central axis of the pockmark, densities are highly heterogeneous and range from 2472 individuals per $\mathrm{m}^{2}$ at $\mathrm{V} 2$ to 22305 individuals per $\mathrm{m}^{2}$ at M3 (Table 2).

The vertical distribution of the macrofauna as a whole and of the polychaetes reveals distinctions between two groups of sites (Figure 4). Along the radial, at $\mathrm{O} 2$ and at the two siboglinid sites, the macrofauna and the polychaetes are mostly found in the first three to five centimetres of sediments. At M3 and at the two vesicomyid sites, the polychaetes in particular are distributed deeper in the sediments. The trend is particularly obvious at V3 where half of the macrofauna and the polychaetes are found in the below $10 \mathrm{~cm}$.

Diversity patterns are assessed from polychaetes identified at the family level (Table 3 ). In total, 37 polychaete families were collected; 33 were present in background sediments and 23 in the pockmark area. The difference seems to be mainly related to sampling effort (Figure 5). The cumulative area sampled in the pockmark $\left(0.2 \mathrm{~m}^{2}\right)$ is smaller than the size of one single box core $\left(0.25 \mathrm{~m}^{2}\right)$ but the number of families sampled (23 families) is close to the mean number of polychaete families per box core (22). Although mean taxon richness is similar in sediments in and out of the pockmark, the taxonomic diversity is higher in background sediments (Figure 6) due to lower densities and higher evenness (Table 3). The ES(n) index is significantly different between sites within and outside the pockmark area, whether $\mathrm{O} 1$ is included among sites within the pockmark or not $(\mathrm{O} 1$ included: $U=42, p=0.004$; O1 excluded: $U=35, p=0.006$ ). Alpha diversity thus is lower in seep sediments. It is noteworthy however, that the slope of accumulation curves in Figure 5 and Figure 6 are steeper for samples within than outside the pockmark, which may suggest higher beta diversity in seep sediments.

Along the radial, diversity indices show only slight variations among sites (Table 3). There is however, a trend of decreasing diversity away from the active centre of the pockmark. The 
correlation between diversity and distance is marginally significant for the Simpson index (linear model, $r^{2}=0.64, p=0.05$ ) as well as Shannon and Hurlbert indices (linear model, $\left.r^{2}=0.64, p=0.06\right)$. Within the pockmark area, the sites $V 1$ and M3 are systematically the most diverse, while the rank of the other sites varies according to the index considered (Table 3).

Three groups of samples can be identified in the clustering and PCA results (Figure 7 and Figure 8). The distinction between samples located within the pockmark and the samples located outside or in the periphery is evident along the first axis of the PCA, which explains $46 \%$ of total variance. The faunal composition is very similar between samples from background sediments. Among the few outliners, one core from R7 and one core from $\mathrm{O} 1$ were in fact located in or near fields of dead vesicomyids, just as O2. It is noteworthy that while $\mathrm{O} 1$ was sampled with a blade corer, it is consistently plotted with box cores from a similar habitat suggesting that the patterns revealed by the PCA are not related to a sampling bias.

Within the pockmark area, there is a difference between the siboglinid-dominated sites and the bivalve-dominated sites (Figure 8). Within each of these groups, the taxonomic composition is more heterogeneous than in background sediments as shown by higher values of the Hellinger distance in the clustering analysis (Figure 7) and higher dispersion of the samples in the PCA (Figure 8). At V1, M3 and S2 nevertheless, the two cores from each site are more similar to each other than to cores from other sites (Figure 7), suggesting sitespecific macrofaunal assemblages.

The heterogeneity of assemblages in the pockmark area compared to the homogeneity of the background community can be explained by dominance patterns. The taxa that contribute most to the negative end of the first axis of the PCA, such as tanaidaceans or spionid, paraonid and cirratulid polychaetes are dominant in each sample from the background community and to some extent in peripheral samples at R7, $\mathrm{O} 1$ and $\mathrm{O} 2$, while they are absent or rare in the pockmark (Figure 9, Table 2 and Table 3). The taxa that contribute most to the positive end of the first axis, in particular the capitellids and the cossurids are more abundant in seep sediments than in background sediments but achieve their highest densities at bivalve-dominated sites where they contribute to $40 \%, 78 \%$ and $81 \%$ of polychaete densities respectively at V1, M3 and V3. The taxa that contribute most to the second axis of the PCA are characteristic of one or a few sites within the pockmark. The nemerteans and the pilargids are particularly abundant at V1 and M3; the syllids are dominant at S2 while the ampharetids, the dorvilleids and the hesionids are characteristic of S1 (Figure 9 and Table 3).

\section{Discussion}




\subsection{Relationship between megafaunal clusters and macrofaunal assemblages}

The first question we addressed in this study was whether different geochemical settings indicated by the presence of various megafaunal assemblages would influence macrofaunal communities in a cold-seep environment. In the giant Regab pockmark, macrofaunal communities differ from the background communities in terms of density, diversity and composition. The diversity of polychaete families is lower in seep sediments and except at V3 and O1, densities are higher in the pockmark than in background sediments. Mean densities over 22,000 ind. $\mathrm{m}^{-2}$ at the mytilid-dominated site are in the high range of those reported from cold seep sediments (Levin 2005) and follows patterns of nematode biomass at this site (Van Gaever et al. 2009). Similarly high macrofaunal densities were reported from a bacterial mat at the Florida escarpment, at $3290 \mathrm{~m}$ depth, where the heterotrophic macrofauna largely relied upon methane-derived carbon according to stable isotope analyses (Levin \& Mendoza 2007). Higher macrofaunal densities, ranging from 23,000 to 62,000 ind. $\mathrm{m}^{-2}$, were found in seeps located on the upper slope of the continental margin off California and Oregon but at much shallower depths (Levin et al. 2006, Levin et al. this volume).

The mytilid site at Regab is characterized by elevated concentrations of methane in seawater (Olu-Le Roy et al. 2007), consistent with the high densities of anaerobic methane oxidizing (AOM) microbial consortia found in sediments nearby (Cambon-Bonavita et al. 2009). The deep-dwelling macrofauna in the vicinity of the mytilid patch, dominated by sub-surface deposit feeders such as the capitellids and cossurids, is thus expected to feed on this microbial biomass and benefit from methane-derived carbon to achieve high densities.

Beyond diversity and density, the taxonomic composition also clearly differs between seep and non-seep sediments. The seep macrofauna is characterized both by low densities of taxa usually dominant in the deep sea and high densities of usually rare or uncommon taxa. Under-represented taxa in particular are the tanaids or the polychaete families Spionidae, Cirratulidae and Paraonidae (Jumars \& Gallagher 1982; Grassle \& Maciolek 1992; Paterson \& Lambshead 1995; Cosson-Sarradin et al. 1998). By contrast seeps are often dominated by families usually considered as opportunists, for example Dorvilleidae and Hesionidae (Levin 2003; Menot et al. 2009). Other commonly recorded families include Ampharetidae, which is also common in non-seep environments (Levin 2005). Other families such as Capitellidae, Cossuridae and Syllidae have been occasionally recorded from seeps (Levin et al. 2003; Robinson et al. 2004) while this study reports the first occurrence of the Pilargidae as a dominant component of a cold seep macrobenthic community.

At the scale of the pockmark, variations in community composition are consistent among sites. Each of the pairs of cores sampled at S1, M3 and V1 are representative of a few 
square meters in which macrofaunal assemblages are more similar to each other than to other sites. The clustering of these pairs of samples mixes the 'vesicomyid' sites (V1, V3) with the 'mytilid' site (M3) and sets apart the 'siboglinid' sites (S1 and S2). It should be noted that the macrofauna at the mytilid site has been sampled in sediments located at the border between the M3 site described in Olu-Le Roy et al. (2007) and a vesicomyid bed. The sediment parameters measured from cores sampled in association with macrofaunal cores suggest that the geochemical settings are different between the mytilid and the two vesicomyid sites. The density of AOM aggregates, also measured from cores associated to macrofaunal samples, show that microbial abundance is higher at M3 than at V1 and V3 (Cambon-Bonavita et al. 2009). Despite these variations in habitat descriptors, polychaete assemblages at mytilid and vesicomyid sites are similar in that both are dominated by capitellids and cossurids and mainly distributed in sub-surface sediments. The nematodes were also deep dwellers at the same sites (Van Gaever et al. 2009). Capitellids and cossurids were also dominant in a vesicomyid field at northern California methane seeps where they were predominantly found at the sulphide-oxygen interface (Levin et al. 2003). These two polychaete families may be taking advantage of higher microbial biomass in this zone or alternatively be merely more tolerant of sulphides and reside deep in sediments to escape predation and competition with other species (Levin et al. 2003). Measures of sulphides in sediments are not available at the Regab site but the study of the vertical distribution of microbial consortia involved in the anaerobic oxidation of methane (AOM) shows that these AOM aggregates are present from 5 to $7 \mathrm{~cm}$ below the sediment surface and reach a maximum of $10 \mathrm{~cm}$ depth at the vesicomyid sites and $14 \mathrm{~cm}$ depth near the mytilid site (Cambon-Bonavita et al. 2009).

During $\mathrm{AOM}$, methane oxidation is coupled with sulphate reduction (SR) to produce sulphides (Boetius et al. 2000). The vertical distribution of AOM and SR follows that of AOM aggregates (Boetius et al. 2000; Treude et al. 2003). At the Regab site, a peak in densities of polychaetes at vesicomyid sites coincides with the peak of AOM aggregate densities at about $10 \mathrm{~cm}$ below the sediment surface, which suggests that the vertical distribution of polychaetes is mainly governed by food availability. At the mytilid site however a peak in polychaete densities is observed in the sediment layers 1-3 cm and 3-5 cm, just above the distribution of AOM aggregates. As mentioned earlier, M3 is characterized by higher concentrations of methane and higher densities of aggregates, which suggest higher sulphide concentrations in sediments. At the Eel river methane seeps, most macrofaunal taxa avoided sulphide concentration over 1 mM (Levin et al. 2003). At M3, the distribution of polychaetes could thus be a trade-off between sulphide tolerance and food availability The three bivalve-dominated sites likely experience different fluid flows, AOM rates and sulphide concentrations, which might explain variations in densities and vertical distribution. However, 
their taxonomic composition at the family level remains similar. Variations in community composition at the species level can not be excluded but the repeating pattern of dominance by capitellids and cossurids in different environmental settings may suggest some similarities in the functioning of these habitats. In the range of flow rates experienced by the fauna at these sites, fluid flow may thus not be the only factor forcing the functioning of macrobenthic communities. Rather the interplay between flow rate, sulphide concentration and the feeding behaviour of the megafauna (see below) may generate observed communities.

The variations in community composition and vertical distribution at the two sibogliniddominated sites compared to bivalve-dominated sites may provide further clues to factors structuring macrobenthic communities. Unfortunately, environmental data are available for the S2 site but not S1, which limits generalization of the observations. At both sites, the macrofauna is mainly concentrated in the top centimetres of sediments. At S2, a similar pattern was reported for nematodes (M1 site in Van Gaever et al. 2009), while AOM aggregates were found up to the sediment surface (Vest site in Cambon-Bonavita et al. 2009). Organic carbon content also reaches almost $6 \%$ at $S 2$ and strongly decreases below the first centimetre of sediment.. All these pieces of evidence suggest that at sibogliniddominated sites, contrary to bivalve-dominated sites, benthic activity is concentrated in the top layer of sediments, possibly due to methane oxidation and production of sulphides reaching the sediment surface. Both the siboglinids and the vesicomyids grow on sulphides and by their activities in sediments may enhance sulphate reduction but the two taxa use different strategies that variously influence sulphide profiles (Sahling et al. 2002; Levin et al. 2003; Treude et al. 2003; Dattagupta et al. 2008).

The vesicomyids actively dig and pump in sediments to acquire sulphide through their feet (Sahling et al. 2002). This clam venting activity results in an irrigation of sediments with both oxygen, that inhibits AOM in the upper sediments, and sulphates that enhance AOM in the anoxic zone (Sahling et al. 2002; Levin et al. 2003; Treude et al. 2003). The siboglinids on the other hand acquire sulphides and release sulphate using roots buried in sediments. The sediment surface is not disturbed by the activity of the tube-worms and sulphides may reach the sediment surface (Dattagupta et al. 2008).

Cordes et al. (this volume) noted that many of the mechanisms linking heterogeneity to diversity in seeps are facilitative. Our study may provide further evidence of facilitation between megafaunal and macrofaunal communities. Indeed, while the rate of fluid flow may influence macrofaunal densities, it is the vertical distribution of sulphides, mediated by the feeding activities of large symbiont-bearing taxa, that possibly influences the functioning of macrobenthic communities and their taxonomic composition. In or near vesicomyid fields, where the upper sediments are bioturbated, sub-surface deposit feeders such as capitellids and cossurids may benefit from high microbial biomass associated with AOM and are found 
to be dominant. Near the siboglinids, where AOM and sulphide almost reach the surface, the community is dominated by surface-deposit feeders such as the ampharetids or small mobile omnivores such as the dorvilleids, the hesionids and the syllids.

\subsection{Influence of the pockmarks on nearby macrofaunal communities}

At the spatial scale and taxonomic levels considered in this study there is little evidence of an influence of the giant pockmark Regab on nearby macrofaunal communities beyond the limit of peripheral vesicomyid fields. At the sites located from $250 \mathrm{~m}$ to $1000 \mathrm{~m}$ from the active centre of the pockmark, neither variations in densities nor variations in taxonomic composition are correlated with distance from the seeps. Samples taken in or near peripheral vesicomyid field, in particular one core from R7, show enhanced densities compared to the background but the taxonomic composition remains closely related to non-seep communities. The diversity of polychaete families might be slightly enhanced within a radius of $250 \mathrm{~m}$ but taxonomic richness is not, excluding the hypothesis of an ecotone effect whereby taxa with different ecological requirements coexist and enhance diversity at the border between two habitats. Considering the low range of variations in the value of diversity indices, the taxonomic resolution of the study and the fact that the relationship between diversity and distance is only marginally significant, no firm conclusion could in fact reasonably be drawn about an influence of the seeps on the diversity of nearby communities. Studies on the use of chemosynthetic biomass by background vagrants or colonists have shown that a limited number of species exploit the seeps and even fewer export biomass back to the non-seep ecosystem (MacAvoy et al. 2002; Olu-Le Roy et al. 2009). In the Gulf of Mexico, MacAvoy et al. (2002) found three vagrant species that derive a substantial part of their biomass from chemosynthetic production and could be direct exporters of seep production. In the periphery of Regab, chemosynthetic material contribute to $15 \%$ up to $38 \%$ of the diet of five fish species among the 12 species captured in trawls (Olu-Le Roy et al. 2009). Colonization experiments have also shown that the dispersal of macrofaunal species characteristics of seep sediments was very limited in space (Levin et al. 2006). On the other hand, Sahling et al. (2003) suggested that the increasing endemism of the seep fauna with depth is related to a decrease in predation pressure by background species. Hence, while cold seep communities seem to be under the influence of the surrounding ecosystem, there is little evidence to date that cold seep ecosystems largely influence the surrounding communities, although in the present study the coarse taxonomic resolution used can not support firm conclusions. 


\subsection{Relationship between habitat heterogeneity and diversity of the macrofauna}

Alpha diversity of polychaete assemblages at each of the Regab seep site is low but communities are dominated by taxa that are usually rare in deep-sea sediments. Some of them, like the dorvilleids, might have radiated in sulphidic environments and be highly diverse in seeps (Levin et al. 2003, 2006). The taxonomic composition furthermore is variable at small spatial scales. Higher accumulation rates of polychaete families are found within than outside the pockmark area, although sites within the seep are only $60 \mathrm{~m}$ to $230 \mathrm{~m}$ apart while the distance between sites outside the pockmark ranges from 250 to $2000 \mathrm{~m}$. Taxonomic turnover (i.e. beta diversity) is thus higher within the seep than outside it. This pattern might merely be the result of a sampling artifact because the blade cores used to sample seep habitats $\left(0.018 \mathrm{~m}^{2}\right)$ were smaller than the box cores used to sample background sediments $\left(0.25 \mathrm{~m}^{2}\right)$. A sampling artifact would assume that the fauna is patchily distributed at the scale of a box core but studies on the distribution of deep-sea species at this scale usually failed to show significant departure from randomness (Jumars 1975; Jumars 1976, Gage et al. 1995). The aggregation of seep macrofauna on this small spatial scale is likely a true biological pattern that has been repeatedly observed and shown to enhance beta-diversity in this ecosystem (Cordes et al., this volume; Levin et al., this volume). In the present study, we suspect this variability to be related to the dual effect of fluid flow and the biological activity of symbiont-bearing taxa in determining the shape of sulphide profiles and range of sulphide concentrations in sediments. As the vertical distribution and concentration of sulphides may substantially vary over small spatial scales (Levin et al. 2003), beta diversity of macrofaunal communities is potentially high in a large cluster of pockmarks such as Regab. Furthermore, Cold-seep communities are numerous in the Gulf of Guinea at all depths (Cordes et al. 2007; Olu-Le Roy et al. in prep.) and species turnover, along with depth, seems to be important for seep-related megafauna and macroepifauna (Sahling et al. 2003; Cordes et al. 2007), though the same pattern has to be confirmed for macrofaunal communities. Considering specialization on seep environments, species turnover according to geochemical settings within a site and species turnover according to depth between sites, cold-seep ecosystems may significantly contribute to the macrofaunal species pool at a regional scale in the deep Gulf of Guinea. On the upper slope of the NE Pacific margin, Levin et al. (this volume) suggested that Hydrate Ridge seeps off Oregon and Eel River seeps off California may together contribute to $42 \%$ of the regional species collected. In the present study, it is noteworthy that for a similar area sampled, the number of polychaete families is similar within seep and background sediments, although the mechanisms explaining the coexistence of taxa in these two different ecosystems may be different. Cordes et al. (this volume) suggest that niche differentiation may be involved in the structuring of seep assemblages while the demonstration of niche differentiation is open for 
debate among open slope communities (Snelgrove \& Smith 2002). Further comparisons of macrofaunal communities at the species level between seep and non-seep environments may help in understanding biodiversity maintenance and functioning of both ecosystems.

\section{Summary}

Cold seep ecosystems on continental margins exhibit high standing stock and conspicuous habitat fragmentation at small spatial scales. In the deep Gulf of Guinea, the giant pockmark Regab is characterized by the dense aggregation and patchy distribution of siboglinid tubeworms, vesicomyids and mytilids. Despite a low taxonomic resolution, we show that familial assemblages of polychaetes differ between seep and non-seep habitats. Seep sediments are dominated by families usually rare in background sediments. The accumulation rate of polychaete families is higher while the distance between samples is smaller in seep than non-seep sediments. This increase in beta diversity in the pockmark area is related to variations in macrobenthic community structure between bivalve-dominated and sibogliniddominated sites. We suggest that this pattern highlights variations in the functioning of the two communities. Bioturbation induced by vesicomyids in particular is assumed to deepen the oxic/anoxic interface where the anaerobic oxidation of methane (AOM) takes place and AOM microbial consortia aggregate, thus creating a suitable niche for sulphide-tolerant, subsurface-deposit feeders. Without this facilitative mechanism near siboglinid tube-worms, the macrofauna is dominated by surface deposit feeders and mobile omnivores. At the taxonomic level used, we are not able to find an influence of the cold-seep ecosystem on macrofaunal assemblages distributed along the two radials $250 \mathrm{~m}$ to $1000 \mathrm{~m}$ apart from the active centre of the pockmark. However, the original composition of familial assemblages of polychaetes and high beta diversity in seep compared to non-seep sediments, associated with the fact that cold-seep ecosystems seem to be widespread at all depth in the Gulf of Guinea, suggest that these habitats substantially contribute to the regional species pool.

\section{Acknowledgements}

The BIOZAIRE programme has been co-funded by Ifremer and TOTAL. We wish to thank the chief scientists of the Biozaire 1, 2 and 3 cruises, the captain and crews of the N.O. L'Atalante and Victor 6000 as well as all participants to the cruises who actively and tirelessly contribute to dive watches, sample handling and sample processing on board. Special thanks are extended to A. Fifis and S. Dubut who processed the samples in the laboratory. We are grateful to M.-C. Fabri for her careful attention paid to data management. Metadata are archived in the Biocean database and available at 
http://www.ifremer.fr/biocean/indexgb.html. We thank 3 anonymous reviewers for helpful comments and improvements on the manuscript. The Census of Marine Life and Fondation Total are gratefully acknowledged for co-funding of the workshop "Roles of Habitat Heterogeneity in Generating and Maintaining Continental Margin Biodiversity" thoroughly organized by Dr Lisa Levin on behalf of COMARGE. L.M. is a postdoctoral fellow of the Census of Marine Life.

\section{References}

Andersen, A.C., Hourdez, S., Marie, B., Jollivet, D., Lallier, F.H., Sibuet, M. (2004) Escarpia southwardae sp. nov., a new species of vestimentiferan tubeworm (Annelia, Siboglinidae) from West African cold seeps. Canadian Journal of Zoology, 82, 980-999.

Bergquist, D.C., Fleckenstein, C., Knisel, J., Begley, B., MacDonald, I.R., Fisher, C.R. (2005) Variations in seep mussel bed communities along physical and chemical environmental gradients. Marine Ecology Progress Series, 293, 99-108.

Bergquist, D.C., Ward, T., Cordes, E.E., McNelis, T., Howlett, S., Kosoff, R., Hourdez, S., Carney, R., Fisher, C.R. (2003) Community structure of vestimentiferan-generated habitat islands from Gulf of Mexico cold seeps. Journal of Experimental Marine Biology and Ecology, 289(2), 197-222.

Blake, J.A., Grassle, J.F. (1994) Benthic community structure on the U.S. South Atlantic slope off the Carolinas: spatial heterogeneity in a current-dominated system. Deep-Sea Research II, 41(4-6), 835-874.

Boetius, A., Ravenschlag, K., Schubert, C.J., Rickert, D., Widdel, F., Gieseke, A., Amann, R., Jorgensen, B.B., Witte, U., Pfannkuche, O. (2000) A marine microbial consortium apparently mediating anaerobic oxidation of methane. Nature, 407(6804), 623-626.

Bouxin, G. (2005) Ginkgo, a multivariate analysis package. Journal of Vegetation Science, $16,355-359$

Cambon-Bonavita, M.A., Nadalig, T., Roussel, E., Delage, E., Duperron, S., Caprais, J.C., Boetius, A., Sibuet, M. (2009) Diversity and distribution of methane oxidizing microbial communtities associated with different faunal assemblages in a giant pockmark of the Gabon continental margin. Deep-Sea Research II.

Cordes, E.E., Bergquist, D.C., Predmore, B.L., Jones, C., Deines, P., Telesnicki, G., Fisher, C.R. (2006) Alternate unstable states: Convergent paths of succession in hydrocarbonseep tubeworm-associated communities. Journal of Experimental Marine Biology and Ecology, 339(2), 159-176.

Cordes, E.E., Carney, S.L., Hourdez, S., Carney, R.S., Brooks, J.M., Fisher, C.R. (2007) Cold seeps of the deep Gulf of Mexico: Community structure and biogeographic comparisons to Atlantic equatorial belt seep communities. Deep-Sea Research I, 54, 637-653.

Cordes, E.E., Ribeiro da Cunha, M., Galéron, J., Mora, C., Olu-Le Roy, K., Sibuet, M., Van Gaever, S., Vanreusel, A., Levin, L.A. (2009) The influence of geological, geochemical, and biogenic habitat heterogeneity on seep biodiversity. Marine Ecology, DOI:10.1111/j.1439-0485.2009.00334.x. 
Cosel, R. von, Olu, K. (2008) A new genus and new species of Vesicomyidae (Mollusca, Bivalvia) from cold seeps on the Barbados accretionary prism, with comments on other species. Zoosystema, 30, 929-944.

Cosel, R. von, Olu, K. (2009) Large Vesicomyidae (Mollusca: Bivalvia) from cold seeps in the Gulf of Guinea off the coasts of Gabon, Congo and northern Angola. Deep-Sea Research II. doi:10.1016/i.dsr2.2009.04.016

Cosson-Sarradin, N., Sibuet, M., Paterson, G.L.J., Vangriesheim, A. (1998) Polychaete diversity at tropical deep-sea sites: Environmental effects. Marine Ecology Progress Series, 165, 173-185.

Dattagupta, S., Arthur, M.A., Fisher, C.R. (2008) Modification of sediment geochemistry by the hydrocarbon seep tubeworm Lamellibrachia luymesi: A combined empirical and modeling approach. Geochimica et Cosmochimica Acta, 72(9), 2298-2315.

Dinet, A., Desbruyères, D., Khripounoff, A. (1985) Abondances des peuplements macro- et meio-benthiques : répartition et stratégie d'échantillonnage. In: L. Laubier \& C. Monniot (Eds). Peuplements profonds du golfe de Gascogne : campagnes BIOGAS. IFREMER Service Documentation-Publications, Brest: 121-142.

Duperron, S., Nadalig, T., Caprais, J.-C., Sibuet, M., Fiala-Medioni, A., Amann, R., Dubilier, N. (2005) Dual Symbiosis in a Bathymodiolus sp. Mussel from a Methane Seep on the Gabon Continental Margin (Southeast Atlantic): 16S rRNA Phylogeny and Distribution of the Symbionts in Gills. Appl. Environ. Microbiol., 71(4), 1694-1700.

Doerries, M.B., Van Dover, C.L. (2003) Higher-taxon richness as surrogate for species richness in chemosynthetic communities. Deep-Sea Research I, 50, 749-755.

Gage, J.D., Lamont, P.A., Tyler, P.A. (1995) Deep-sea macrobenthic communities at contrasting sites Off Portugal, preliminary results: II Spatial dispersion. Internationale Revue der gesamte Hydrobiology, 80, 251-265.

Galéron, J., Menot, L., Renaud, N., Crassous, P., Khripounoff, A., Treigner, C., Sibuet, M. (2009) Spatial and temporal patterns of deep-sea macrofaunal communities in the Gulf of Guinea. Deep-Sea Research II. doi:10.1016/j.dsr2.2009.04.011

Gotelli, N.J., Entsminger, G.L. (2009) Ecosim: Null models software for ecology. Version 7. Acquired Intelligence INC \& Kesey-Bear http://garyentsminger.com/ecosim.htm, Burlington.

Grassle, J.F., Maciolek, N.J. (1992) Deep-sea species richness: regional and local diversity estimates from quantitative bottom samples. American Naturalist, 139, 313-341.

Hessler, R.R., Jumars, P.A. (1974) Abyssal community analysis from replicate box cores in the central North Pacific. Deep-Sea Research, 21, 185-209.

James, R.J., Lincoln Smith, M.P., Fairweather, P.G. (1995) Sieve mesh-size and taxonomic resolution needed to describe natural spatial variation of marine macrofauna. Marine Ecology Progress Series, 118, 187-198.

Jumars, P.A. (1975) Environmental grain and polychaete species diversity in a bathyal benthic community. Marine Biology, 30, 253-266.

Jumars, P.A. (1976) Deep-sea species diversity: does it have a characteristic scale? Journal of Marine Research, 34, 217-246.

Jumars, P.A., Gallagher, E.G. (1982) Deep-sea community structure: three plays on the benthic proscenium. In: W.G. Ernst \& J.G. Morin (Eds). The Environment of the DeepSea. Prentice Hall, New Jersey: 217-255.

Legendre, L., Gallagher, E.G. (2001) Ecologically meaningful transformations for ordination of species data. Oecologia, 129, 271-280. 
Levin, L.A. (2003) Oxygen minimum zone benthos: Adaptation and community response to hypoxia. Oceanography and Marine Biology: an Annual Review, 41, 1-45.

Levin, L.A. (2005) Ecology of cold seep sediments: Interactions of fauna with flow, chemistry and microbes. Oceanography and Marine Biology: an Annual Review, 43, 1-46.

Levin, L.A., James, D., W., Martin, C.M., Rathburn, A.E., Harris, L.H., Michener, R.H. (2000) Do methane seeps support distinct macrofaunal assemblages? Observations on community structure and nutrition from the northern California slope and shelf. Marine Ecology Progress Series, 208, 21-39.

Levin, L.A., Mendoza, G.F. (2007) Community structure and nutrition of deep methane-seep macrobenthos from the North Pacific (Aleutian) Margin and the Gulf of Mexico (Florida Escarpment). Marine Ecology, 28, 131-151.

Levin, L.A., Mendoza, G.F., Gonzalez, J., Thurber, A.R., Cordes, E.E. (2009) Diversity of macrofauna on the northeastern Pacific margin: the influence of methane seeps and oxygen minimum zones. Marine Ecology, DOI:10.1111/j.1439-0485.2009.00335.x.

Levin, L.A., Ziebis, W., Mendoza, G.F., Growney-Cannon, V., Walther, S. (2006) Recruitment response of methane-seep macrofauna to sulfide-rich sediments: An in situ experiment. Journal of Experimental Marine Biology and Ecology, 330(1), 132-150.

Levin, L.A., Ziebis, W., Mendoza, G.F., Growney, V.A., Tryons, M.D., Brown, K.M., Mahn, C., Gieske, J.M., Rathburn, A.E. (2003) Spatial heterogeneity of macrofauna at northern California methane seeps: influence of sulfide concentration and fluid flow. Marine Ecology Progress Series, 265, 123-130.

MacAvoy, S.E., Carney, R.S., Fisher, C.R., Macko, S.A. (2002) Use of chemosynthetic biomass by large, mobile, benthic predators in the Gulf of Mexico. Marine Ecology Progress Series, 225, 65-78.

Menot, L., Crassous, P., Desbruyeres, D., Galéron, J., Khripounoff, A., Sibuet, M. (2009) Colonization patterns along the equatorial West African margin: Implications for functioning and diversity maintenance of bathyal and abyssal communities. Deep-Sea Research II. doi:10.1016/j.dsr2.2009.04.012

Narayanaswamy, B.E., Nickell, T.D., Gage, J.D. (2003) Appropriate levels of taxonomic discrimination in deep-sea studies: species vs family. Marine Ecology Progress Series, 257, 59-68.

Oksanen, J., Kindt, R., Legendre, P., O'Hara, B., Simpson, G.L., Solymos, P., Stevens, M.H.H., H., W. (2008) vegan: Community Ecology Package. R package version 1.15-0. http://vegan.r-forge.r-project.org/.

Olsgard, F., Brattegard, T., Holthe, T. (2003) Polychaetes as surrogates for marine biodiversity: lower taxonomic resolution and indicator groups. Biodiversity and Conservation, 12, 1033-1049.

Olu-Le Roy, K., Caprais, J.C., Fifis, A., Fabri, M.C., Galéron, J., Budzinsky, H., Le Ménach, K., Khripounoff, A., Ondréas, H., Sibuet, M. (2007) Cold-seep assemblages on a giant pockmark off West Africa: spatial patterns and environmental control. Marine Ecology, 28, 115-130.

Olu-Le Roy, K., Caprais, J.C., Galéron, J., Causse, R., Cosel, R.v., Budzinsky, H., Le Ménach, K., Le Roux, C., Levaché, D., Khripounoff, A., Sibuet, M. (2009) Influence of seep emission on the non symbiont-bearing fauna and vagrant species at an active giant pockmark in the Gulf of Guinea (Congo-Angola margin). Deep-Sea Research II. doi:10.1016/j.dsr2.2009.04.017 
Olu-Le Roy, K., Cosel, R.v., Hourdez, S., Carney, S.L., Jollivet, D. (2007) Amphi-Atlantic cold-seep Bathymodiolus species complexes across the equatorial belt. Deep Sea Research I, 54(11), 1890-1911.

Ondréas, H., Olu, K., Fouquet, Y., Charlou, J., Gay, A., Dennielou, B., Donval, J., Fifis, A., Nadalig, T., Cochonat, P., Cauquil, E., Bourillet, J., Moigne, M., Sibuet, M. (2005) ROV study of a giant pockmark on the Gabon continental margin. Geo-Marine Letters, 25(5), 281-292.

Paterson, G.L.J., Lambshead, P.J.D. (1995) Bathymetric patterns of polychaete diversity in the Rockall Trough, northeast Atlantic. Deep-Sea Research II, 42, 1199-1214.

Robinson, C.A., Bernhard, J.M., Levin, L.A., Mendoza, G.F., Blanks, J.K. (2004) Surficial Hydrocarbon Seep Infauna from the Blake Ridge (Atlantic Ocean, $2150 \mathrm{~m}$ ) and the Gulf of Mexico (690-2240 m). Marine Ecology, 25, 313-336.

Sahling, H., Galkin, S.V., Salyuk, A., Greinert, J., Foerstel, H., Piepenburg, D., Suess, E. (2003) Depth-related structure and ecological significance of cold-seep communities--a case study from the Sea of Okhotsk. Deep-Sea Research I, 50(12), 1391-1409.

Sahling, H., Rickert, D., Lee, D., Linke, R.W., Suess, E. (2002) Macrofaunal community structure and sulfide flux at hydrate deposits from the Cascadia convergent margin. Marine Ecology Progress Series, 231, 121-138.

Sibuet, M., Olu-Le Roy, K. (2002) Cold seep communities on continental margins: Structure and quantitative distribution relative to geological and fluid venting patterns. In: G. Wefer, D. Billet, D. Hebbelnet al (Eds). Ocean Margin Systems. Springer, Berlin: 235-251.

Sibuet, M., Olu-Le Roy, K. (1998) Biogeography, biodiversity and fluid dependence of deep sea cold seeps communities at active and passive margins. Deep-Sea Research II, 45, 517-567.

Sibuet, M., Vangriesheim, A. (2009) Deep-Sea Environment and Biodiversity of the West African Equatorial margin. Deep-Sea Research II.

Snelgrove, P.V.R., Smith, C.R. (2002) A riot of species in an environmental calm; The paradox of the species-rich deep sea. Oceanography and Marine Biology: an Annual Review, 40, 311-342.

Soetaert, K., Heip, C. (1990) Sample-size dependence of diversity indices and the determination of sufficient sample size in a high-diversity deep-sea environment. Marine Ecology Progress Series, 59, 305-307.

Thioulouse, J., Chessel, D., Dolédec, S., Olivier, J.M. (1997) ADE-4: a multivariate analysis and graphical display software. Statistics and Computing, 7, 75-83.

Treude, T., Boetius, A., Knittel, K., Wallmann, K., Jorgensen, B.B. (2003) Anaerobic oxidation of methane above gas hydrates at Hydrate Ridge, NE Pacific Ocean. Marine Ecology Progress Series, 264, 1-14.

Van Gaever, S., Galéron, J., Sibuet, M., Vanreusel, A. (in press) Unravelling deep-sea habitat heterogeneity based on meiofauna communities in the Gulf of Guinea. Deep-Sea Research II. doi:10.1016/j.dsr2.2009.04.008 
Table 1: Description of the study sites within the pockmarks and available samples (CL: blade cores, macrofaunal samples; CT: tube cores, sediment samples used for measurements of organic carbon, water content, and oxygen).

\begin{tabular}{|c|c|c|c|c|}
\hline Site & Cruise & Dive $n^{\circ}$ & Sample $n^{\circ}$ & Description \\
\hline O1 & Biozaire 1 & 81 & CL3 & $\begin{array}{l}\text { Adjacent to a field of dead } \\
\text { vesicomyids, at the north-eastern } \\
\text { edge of Regab }\end{array}$ \\
\hline S1 & Biozaire 1 & 81 & CL1 & $\begin{array}{l}\text { At the foot of a carbonate concretion } \\
\text { with erect siboglinid tube-worms, in } \\
\text { the active centre of Regab }\end{array}$ \\
\hline S2 & Biozaire 2 & 146 & $\begin{array}{l}\text { CL2, CL8 } \\
\text { CT6, CT7 }\end{array}$ & $\begin{array}{l}\text { At the foot of a carbonate concretion } \\
\text { with erect siboglinid tube-worms, at } \\
\text { the south-western edge of the active } \\
\text { area }\end{array}$ \\
\hline V1 & Biozaire 2 & 145 & $\begin{array}{l}\text { CL5, CL6 } \\
\text { CT3, CT4 }\end{array}$ & $\begin{array}{l}\text { In a large field of mainly living } \\
\text { vesicomyids, at the south-western } \\
\text { edge of Regab }\end{array}$ \\
\hline V3 & Biozaire 2 & 147 & $\begin{array}{l}\text { CL7, CL8 } \\
\text { CT7, CT12 }\end{array}$ & $\begin{array}{l}\text { Adjacent to a cluster of mainly living } \\
\text { vesicomyids, at the north-eastern } \\
\text { edge of the active centre of the } \\
\text { pockmark }\end{array}$ \\
\hline M3 & Biozaire 2 & 147 & $\begin{array}{l}\text { CL2, CL5 } \\
\text { CT14, CT15 }\end{array}$ & $\begin{array}{l}\text { Adjacent to a patch of mytilids } \\
\text { surrounded by vesicomyids, in the } \\
\text { active centre of Regab }\end{array}$ \\
\hline
\end{tabular}


Table 2: Mean densities of macrofaunal taxa outside and within the pockmark, values are given per core, total densities are given per core and normalized to a square meter.

\begin{tabular}{|c|c|c|c|c|c|c|c|c|c|c|c|c|c|}
\hline & R3* & $\mathrm{R}^{*}{ }^{*}$ & $\mathrm{R6}^{*}$ & $\mathrm{R}^{*}$ & $\mathbf{R 9}^{*}$ & R10* & 02 & 01 & S1 & S2 & M3 & V1 & V3 \\
\hline Porifera & $\overline{0.0}$ & 0.7 & 0.0 & 1.3 & 0.7 & $\overline{0.0}$ & 0.0 & 0.0 & $\overline{0.0}$ & 0.0 & $\overline{0.0}$ & $\overline{0.0}$ & $\overline{0.0}$ \\
\hline Cnidaria & 4.0 & 2.3 & 2.0 & 1.0 & 0.0 & 2.3 & 0.5 & 0.0 & 0.0 & 0.0 & 0.0 & 0.0 & 0.0 \\
\hline $\begin{array}{l}\text { Platyhelmint } \\
\text { he }\end{array}$ & 0.0 & 0.0 & 0.0 & 0.0 & 0.0 & 0.0 & 0.0 & 0.0 & 0.0 & 2.5 & 50.0 & 15.5 & 3.5 \\
\hline Nemertea & 15.0 & 24.7 & 17.7 & 53.7 & 29.0 & 14.7 & 14.0 & 1.0 & 1.0 & 0.5 & 13.5 & 33.5 & 3.5 \\
\hline Aplacophora & 5.0 & 4.7 & 8.3 & 10.0 & 7.0 & 12.0 & 5.5 & 0.0 & 0.0 & 0.0 & 0.0 & 0.0 & 0.0 \\
\hline Gastropoda & 2.0 & 2.7 & 3.3 & 17.0 & 3.3 & 3.7 & 3.0 & 0.0 & 22.0 & 2.0 & 3.0 & 0.0 & 0.0 \\
\hline Bivalvia & 48.3 & 91.7 & 83.3 & 126.7 & 75.7 & 84.0 & 46.0 & 6.0 & 19.0 & 2.0 & 10.5 & 7.0 & 0.5 \\
\hline Scaphopoda & 2.3 & 0.7 & 2.0 & 2.3 & 0.0 & 1.0 & 1.0 & 2.0 & 0.0 & 0.0 & 0.0 & 0.0 & 0.0 \\
\hline Echiura & 0.0 & 0.3 & 0.7 & 0.0 & 0.0 & 0.3 & 0.0 & 0.0 & 0.0 & 0.0 & 0.0 & 0.0 & 0.0 \\
\hline Sipuncula & 0.0 & 4.3 & 6.7 & 53.3 & 10.0 & 2.7 & 0.0 & 0.0 & 0.0 & 1.0 & 1.5 & 0.0 & 0.0 \\
\hline Crustacea & & & & & & & & & & & & & \\
\hline Decapoda & 0.0 & 0.0 & 0.0 & 0.0 & 0.0 & 0.3 & 0.0 & 0.0 & 0.0 & 0.0 & 0.0 & 0.0 & 0.0 \\
\hline Cumacea & 1.0 & 3.0 & 4.3 & 7.3 & 3.0 & 4.7 & 3.0 & 0.0 & 0.0 & 0.5 & 0.0 & 1.5 & 0.5 \\
\hline Leptostraca & 0.3 & 1.0 & 0.3 & 0.0 & 0.7 & 0.3 & 0.0 & 0.0 & 0.0 & 0.0 & 0.0 & 0.0 & 0.0 \\
\hline Tanaidacea & 21.7 & 49.0 & 54.7 & 108.0 & 49.0 & 50.3 & 38.5 & 21.0 & 0.0 & 3.0 & 0.0 & 0.0 & 2.0 \\
\hline Isopoda & 28.7 & 37.0 & 51.0 & 79.7 & 41.7 & 50.3 & 46.0 & 8.0 & 0.0 & 15.5 & 0.0 & 2.5 & 0.5 \\
\hline Amphipoda & 8.3 & 11.7 & 9.0 & 17.3 & 8.3 & 7.7 & 7.5 & 0.0 & 0.0 & 0.0 & 0.5 & 0.5 & 0.0 \\
\hline Bryozoa & 1.7 & 9.0 & 0.0 & 0.0 & 0.0 & 0.3 & 0.0 & 0.0 & 0.0 & 1.0 & 0.0 & 0.0 & 0.0 \\
\hline $\begin{array}{l}\text { Echinoderma } \\
\text { ta }\end{array}$ & 9.3 & 8.0 & 7.7 & 10.3 & 8.7 & 11.3 & 8.5 & 3.0 & 0.0 & 1.5 & 0.0 & 1.0 & 0.0 \\
\hline Tunicata & 0.0 & 0.0 & 0.0 & 0.0 & 0.3 & 0.0 & 0.0 & 0.0 & 0.0 & 0.0 & 0.0 & 0.0 & 0.0 \\
\hline $\begin{array}{l}\text { Siphonophor } \\
\text { a }\end{array}$ & 0.0 & 0.0 & 0.0 & 0.0 & 0.7 & 0.0 & 0.0 & 0.0 & 0.0 & 0.0 & 0.0 & 0.0 & 0.0 \\
\hline Annelida & 282.3 & 367.7 & 274.7 & 489.3 & 314.3 & 322.7 & 190.5 & 34.0 & 100.0 & 65.5 & 322.5 & 45.6 & 34.0 \\
\hline $\begin{array}{ll}\text { Total } & \text { (pe } \\
\text { core) }\end{array}$ & 430.0 & 618.3 & 525.7 & 977.3 & 552.3 & 568.7 & 364.0 & 75.0 & 142.0 & 95.0 & 401.5 & 107.1 & 44.5 \\
\hline $\begin{array}{l}\text { Total } \\
\mathrm{m}^{2} \text { ) }\end{array}$ & $\begin{array}{c}1720 . \\
0\end{array}$ & $\begin{array}{c}2473 . \\
3\end{array}$ & $\begin{array}{c}2102 . \\
7\end{array}$ & $\begin{array}{c}3909 . \\
3\end{array}$ & $\begin{array}{c}2209 . \\
3\end{array}$ & 2274. & $\begin{array}{c}1456 . \\
0\end{array}$ & $\begin{array}{c}4166 . \\
7\end{array}$ & $\begin{array}{c}7888 . \\
9\end{array}$ & $\begin{array}{c}5277 \\
8\end{array}$ & 22305. & $\begin{array}{c}5947 . \\
?\end{array}$ & $\begin{array}{c}2472 \\
2\end{array}$ \\
\hline
\end{tabular}

* Data are from Galéron et al. (2009) 
Table 3: Mean densities and taxonomic richness and diversity of polychaetes outside and within the pockmark, values of density are given per core, total densities are given per core and normalized to a square meter.

\begin{tabular}{|c|c|c|c|c|c|c|c|c|c|c|c|c|c|}
\hline & R3* & $\mathbf{R}^{*}{ }^{*}$ & $\mathrm{R}^{*}$ * & $\mathrm{R7}^{*}$ & R9* & R10* & 02 & 01 & S1 & $\mathbf{S 2}$ & M3 & V1 & V3 \\
\hline Acrocirridae & 2.7 & 3.0 & 1.7 & 4.0 & 1.0 & 1.3 & 0.0 & 0.0 & 0.0 & 0.0 & 0.5 & 0.0 & 0.0 \\
\hline Alciopidae & 0.0 & 0.0 & 0.0 & 0.0 & 0.0 & 0.0 & 0.0 & 0.0 & 0.0 & 0.0 & 0.0 & 0.1 & 0.0 \\
\hline Ampharetidae & 1.3 & 1.3 & 0.3 & 1.0 & 0.3 & 0.0 & 0.0 & 0.0 & 67.0 & 0.5 & 0.5 & 0.5 & 0.0 \\
\hline Amphinomidae & 2.0 & 4.7 & 6.7 & 7.3 & 4.7 & 3.0 & 4.5 & 1.0 & 0.0 & 0.0 & 0.5 & 0.0 & 0.5 \\
\hline Aphroditidae & 0.0 & 0.0 & 0.0 & 0.0 & 0.0 & 0.0 & 0.0 & 0.0 & 0.0 & 0.0 & 0.0 & 0.0 & 0.5 \\
\hline Capitellidae & 1.7 & 2.3 & 2.0 & 6.0 & 2.3 & 3.3 & 3.5 & 0.0 & 1.0 & 8.0 & 152.5 & 9.5 & 18.0 \\
\hline Chrysopetalidae & 2.0 & 1.3 & 0.3 & 0.3 & 2.3 & 0.7 & 0.0 & 0.0 & 0.0 & 0.0 & 0.0 & 0.0 & 0.0 \\
\hline Cirratulidae & 42.3 & 60.3 & 44.3 & 57.7 & 49.3 & 40.3 & 32.5 & 22.0 & 0.0 & 0.5 & 5.5 & 0.5 & 1.0 \\
\hline Cossuridae & 2.7 & 3.0 & 3.3 & 12.7 & 4.3 & 1.7 & 3.5 & 0.0 & 0.0 & 4.5 & 98.0 & 9.0 & 9.5 \\
\hline Dorvilleidae & 2.7 & 4.7 & 3.3 & 5.7 & 6.7 & 4.0 & 3.5 & 1.0 & 16.0 & 2.5 & 6.5 & 1.0 & 0.5 \\
\hline Fauveliopsidae & 1.0 & 3.3 & 2.3 & 2.0 & 1.7 & 0.7 & 0.0 & 0.0 & 0.0 & 0.0 & 0.0 & 0.0 & 0.0 \\
\hline Flabelligeridae & 0.7 & 0.7 & 1.3 & 1.3 & 0.7 & 1.0 & 1.0 & 0.0 & 0.0 & 0.0 & 0.0 & 0.0 & 0.0 \\
\hline Goni & 0.0 & 0.0 & 0.0 & 0.0 & 0.3 & 0.3 & 0.0 & 0.0 & 0.0 & 0.0 & 0.0 & 0.0 & 0.0 \\
\hline Glyc & 4.7 & 5.3 & 3.3 & 6.3 & 4.7 & 4.0 & 6.5 & 2.0 & 0.0 & 0.0 & 0.0 & 0.0 & 0.0 \\
\hline Hesio & 1.7 & 0.7 & 1.7 & 2.3 & 2.3 & 2.3 & 1.0 & 0.0 & 11.0 & 1.5 & 6.5 & 1.5 & 1.0 \\
\hline Lumbrineridae & 17.7 & 18.0 & 10.3 & 22.7 & 18.3 & 19.7 & 10.0 & 1.0 & 0.0 & 0.5 & 0.0 & 0.0 & 0.0 \\
\hline Maldanidae & 1.7 & 0.7 & 9.3 & 6.7 & 2.3 & 0.3 & 0.5 & 0.0 & 0.0 & 0.5 & 1.5 & 0.0 & 0.0 \\
\hline Neph & 8.0 & 14.3 & 7.7 & 15.7 & 7.0 & 10.0 & 3.5 & 0.0 & 0.0 & 0.0 & 0.0 & 0.0 & 0.0 \\
\hline Nere & 0.0 & 0.7 & 0.7 & 7.3 & 1.3 & 0.0 & 0.5 & 0.0 & 0.0 & 0.0 & 0.0 & 0.0 & 0.0 \\
\hline Ophe & 20.7 & 21.7 & 18.3 & 43.0 & 18.7 & 23.7 & 9.5 & 0.0 & 0.0 & 0.0 & 0.5 & 1.0 & 0.0 \\
\hline Orbi & 0. & 0.0 & 0.0 & 0.0 & 0.3 & 0.0 & 0.0 & 0.0 & 0.0 & 0.0 & 0.5 & 0.0 & 0.0 \\
\hline Pholoidae & 3.3 & 3.3 & 3.3 & 5.0 & 6.3 & 6.0 & 3.0 & 1.0 & 0.0 & 0.0 & 0.5 & 0.0 & 0.0 \\
\hline Paraonidae & 45.7 & 46.7 & 37.3 & 61.7 & 47.0 & 38.0 & 25.0 & 0.0 & 0.0 & 0.0 & 0.0 & 0.5 & 0.0 \\
\hline Phyllodocidae & 1.7 & 1.0 & 1.7 & 0.3 & 0.0 & 0.0 & 0.0 & 0.0 & 3.0 & 0.0 & 0.5 & 0.0 & 0.0 \\
\hline Pilargidae & 10.0 & 18.3 & 13.7 & 15.3 & 18.0 & 12.3 & 18.0 & 5.0 & 0.0 & 0.5 & 8.5 & 20.0 & 2.0 \\
\hline Polynoidae & 0.0 & 0.0 & 0.3 & 0.0 & 0.7 & 7.7 & 0.0 & 0.0 & 0.0 & 0.0 & 0.0 & 0.0 & 0.0 \\
\hline Sabellidae & 6.7 & 8.3 & 0.7 & 2.7 & 4.3 & 1.0 & 11.0 & 0.0 & 0.0 & 0.0 & 0.0 & 0.0 & 0.0 \\
\hline Scalibregmatidae & 0.0 & 0.0 & 0.0 & 0.0 & 0.3 & 0.0 & 0.0 & 0.0 & 0.0 & 0.0 & 0.0 & 0.0 & 0.0 \\
\hline Siboglinidae & 0.3 & 0.0 & 5.0 & 0.3 & 2.3 & 6.7 & 0.0 & 0.0 & 0.0 & 0.0 & 0.0 & 0.0 & 0.0 \\
\hline Sigalionidae & 2.0 & 4.0 & 4.7 & 4.3 & 2.7 & 2.0 & 1.5 & 0.0 & 0.0 & 1.5 & 0.5 & 1.0 & 0.5 \\
\hline Sphaerodoridae & 5.7 & 10.0 & 6.3 & 7.0 & 7.0 & 7.0 & 4.0 & 0.0 & 1.0 & 0.0 & 3.0 & 0.5 & 0.0 \\
\hline Spionidae & 80.0 & 105.7 & 73.7 & 122.7 & 77.3 & 104.0 & 46.5 & 1.0 & 1.0 & 1.5 & 36.0 & 0.5 & 0.0 \\
\hline Sternaspidae & 0.0 & 1.0 & 0.0 & 0.0 & 0.0 & 0.3 & 0.0 & 0.0 & 0.0 & 0.0 & 0.0 & 0.0 & 0.0 \\
\hline Syllidae & 9.3 & 9.3 & 3.3 & 36.7 & 8.0 & 8.3 & 1.5 & 0.0 & 0.0 & 43.0 & 0.5 & 0.0 & 0.5 \\
\hline Terebellidae & 0.3 & 0.0 & 0.0 & 0.3 & 0.0 & 0.0 & 0.0 & 0.0 & 0.0 & 0.0 & 0.0 & 0.0 & 0.0 \\
\hline Trichobranchidae & 0.0 & 0.0 & 1.3 & 1.7 & 0.3 & 0.7 & 0.0 & 0.0 & 0.0 & 0.5 & 0.0 & 0.0 & 0.0 \\
\hline Paralacydoniidae & 0.0 & 0.0 & 0.7 & 0.0 & 0.0 & 0.0 & 0.0 & 0.0 & 0.0 & 0.0 & 0.0 & 0.0 & 0.0 \\
\hline Undeterm. & 4.0 & 14.0 & 5.7 & 29.3 & 11.3 & 12.3 & 0.0 & 0.0 & 0.0 & 0.0 & 0.0 & 0.0 & 0.0 \\
\hline $\mathrm{Nb}$ of taxa & 27 & 27 & 30 & 29 & 31 & 28 & 21 & 8 & 7 & 13 & 18 & 13 & 10 \\
\hline$E S(n=30)$ & 10.2 & 10.5 & 10.9 & 11.2 & 10.9 & 10.6 & 10.7 & 7.4 & 4.5 & 5.0 & 5.1 & 5.6 & 4.7 \\
\hline $\log _{2} H^{\prime}$ & 3.4 & 3.4 & 3.6 & 3.6 & 3.6 & 3.4 & 3.4 & 1.8 & 1.5 & 1.9 & 2.1 & 2.4 & 2.0 \\
\hline $\mathrm{J}^{\prime}$ & 0.7 & 0.7 & 0.7 & 0.7 & 0.7 & 0.7 & 0.8 & 0.6 & 0.5 & 0.5 & 0.5 & 0.6 & 0.6 \\
\hline 1/D Simpson & 6.9 & 6.8 & 7.6 & 8.0 & 7.8 & 6.4 & 8.1 & 2.3 & 2.1 & 2.2 & 3.0 & 3.8 & 2.9 \\
\hline
\end{tabular}



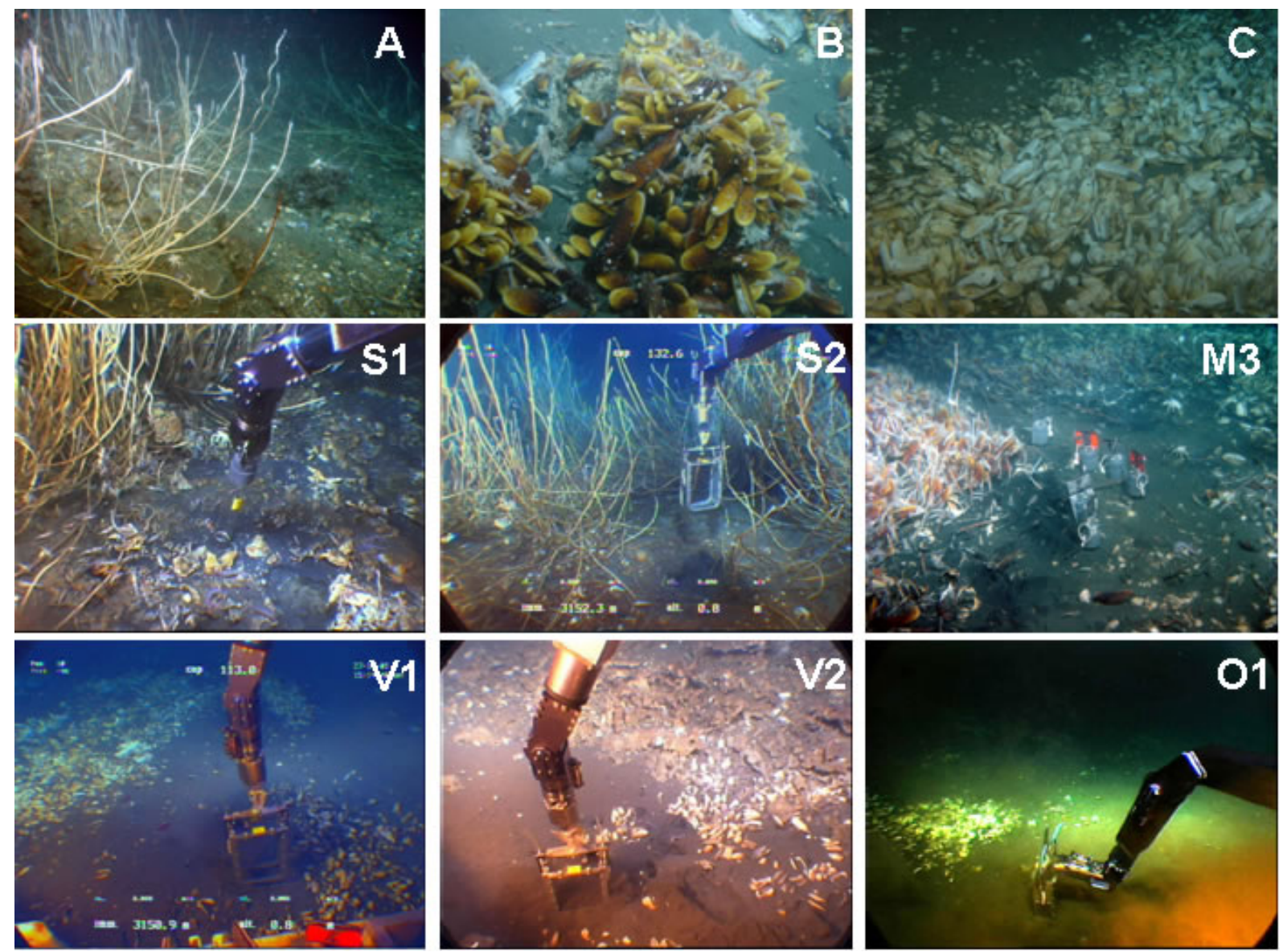

Figure 1

Figure 1: Images of a siboglinid tube-worm bush (A), a patch of mytilids (B), a field of living vesicomyids $(C)$, and images of the sampling sites within the pockmark area. 


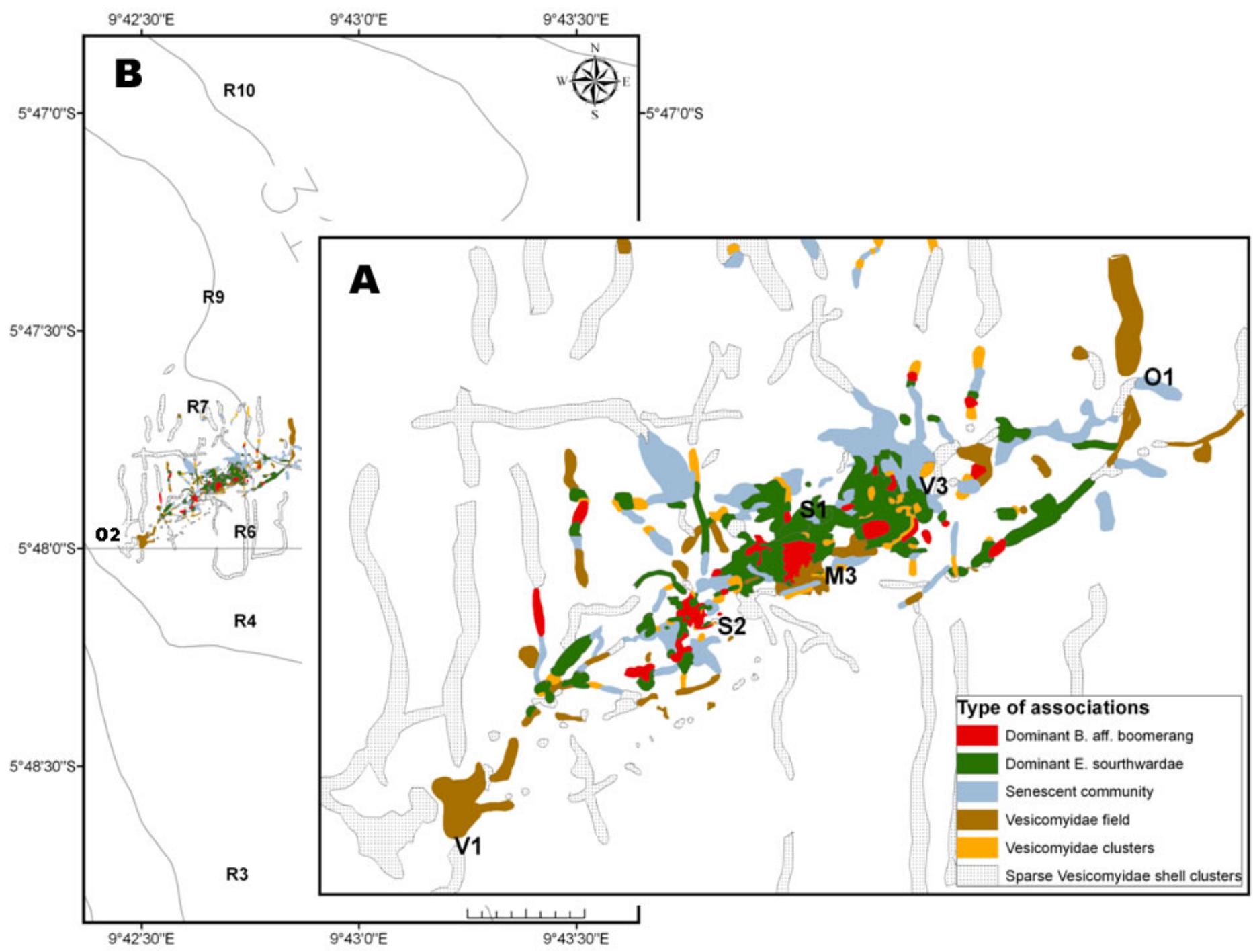

Figure 2: Distribution map of megafaunal assemblages and sampling sites within the pockmark area (A) and localization of the sampling sites along the radials outside the pockmark (B), modified from Olu-Leroy et al. (2007). 

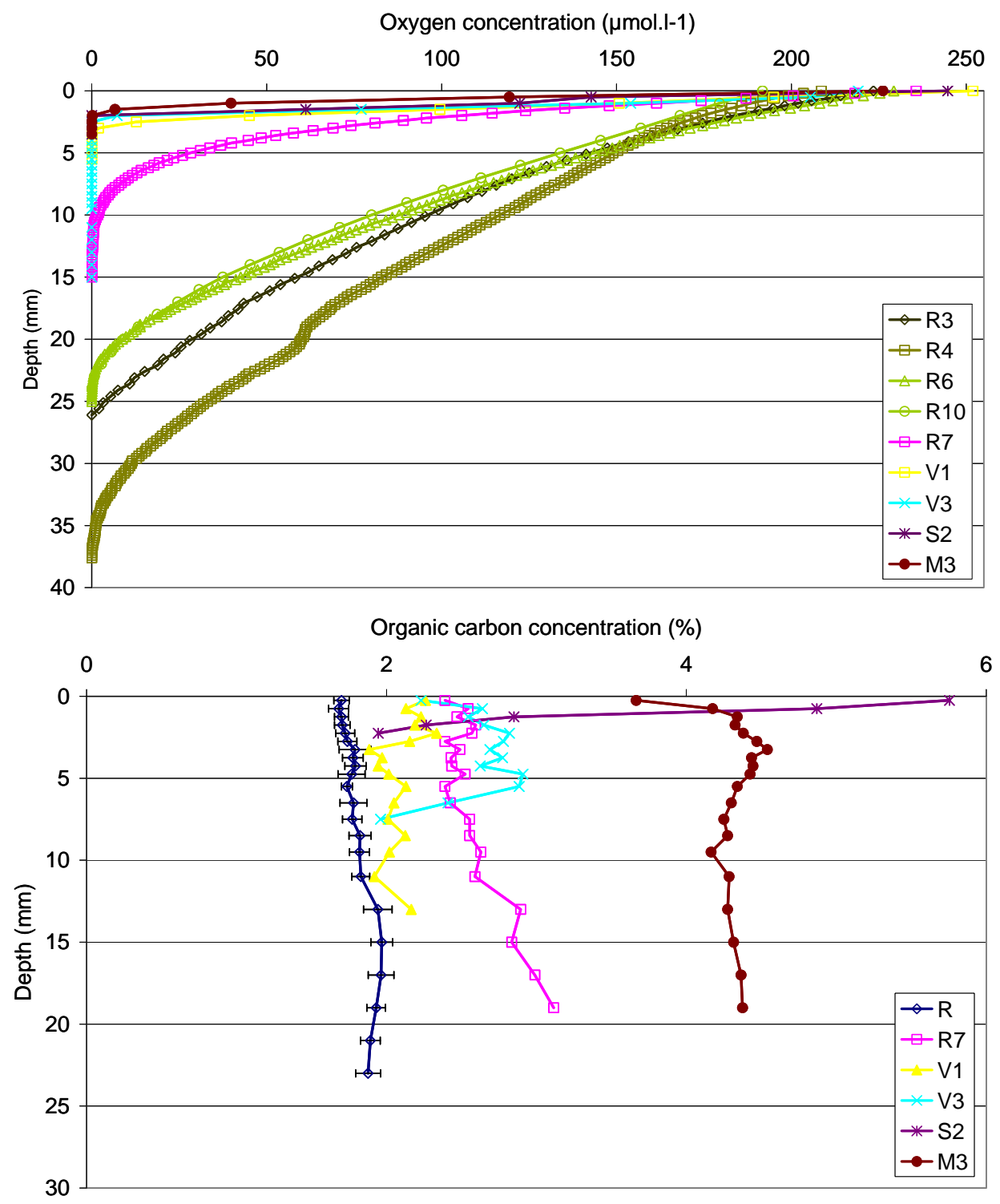

Figure 3

Figure 3: Sediment profiles of organic carbon content and oxygen concentrations within and outside the pockmark area ( $\mathrm{R}$ denotes the mean for sites along the radials, except $\mathrm{R} 7$; error bars are 95\% confidence intervals). 

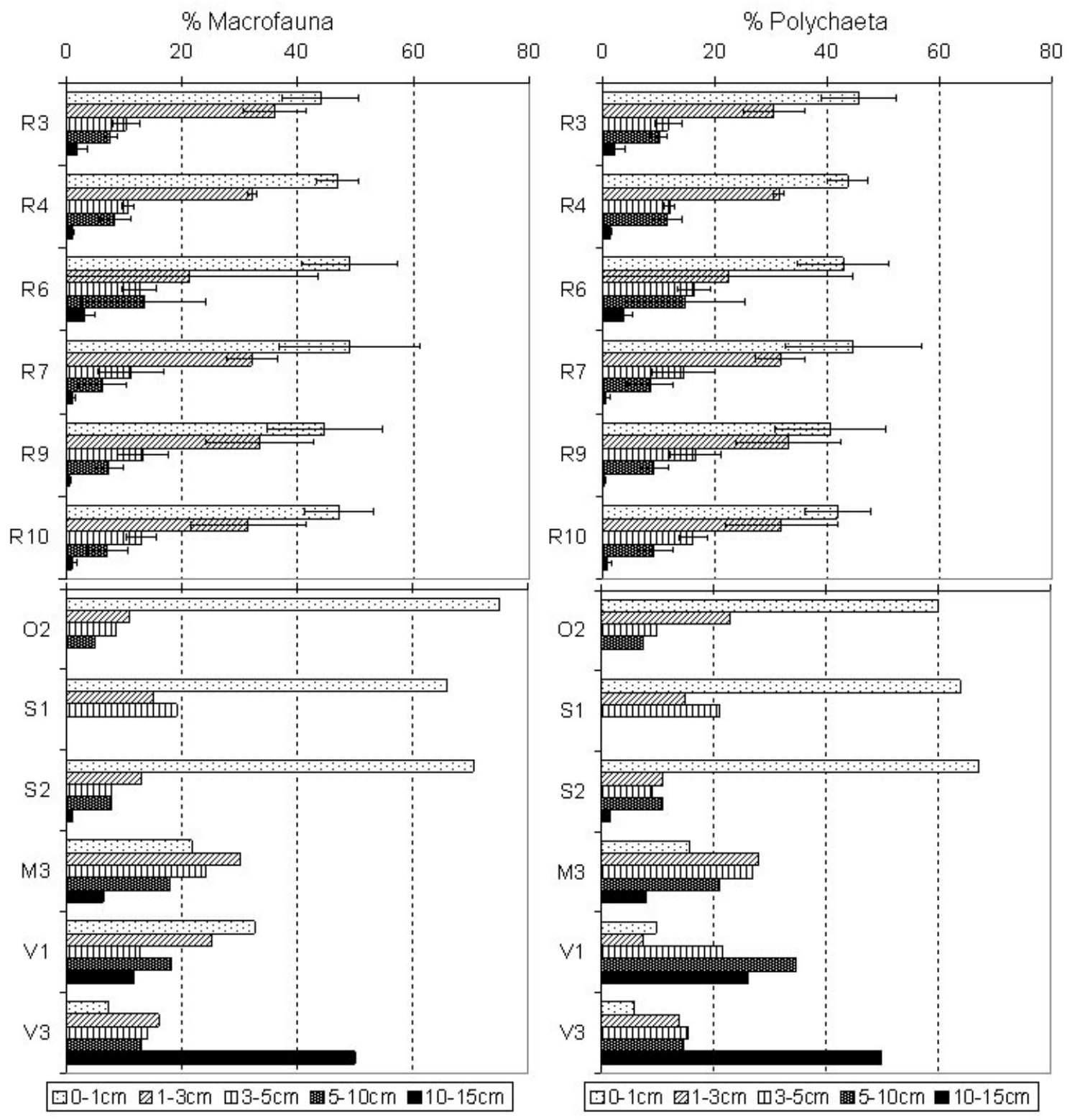

Figure 4

Figure 4: Vertical distribution of the macrofauna (left panel) and the polychaetes (right panel) along the radials outside the pockmark area (upper panel) and within seep sediments (lower panel). 


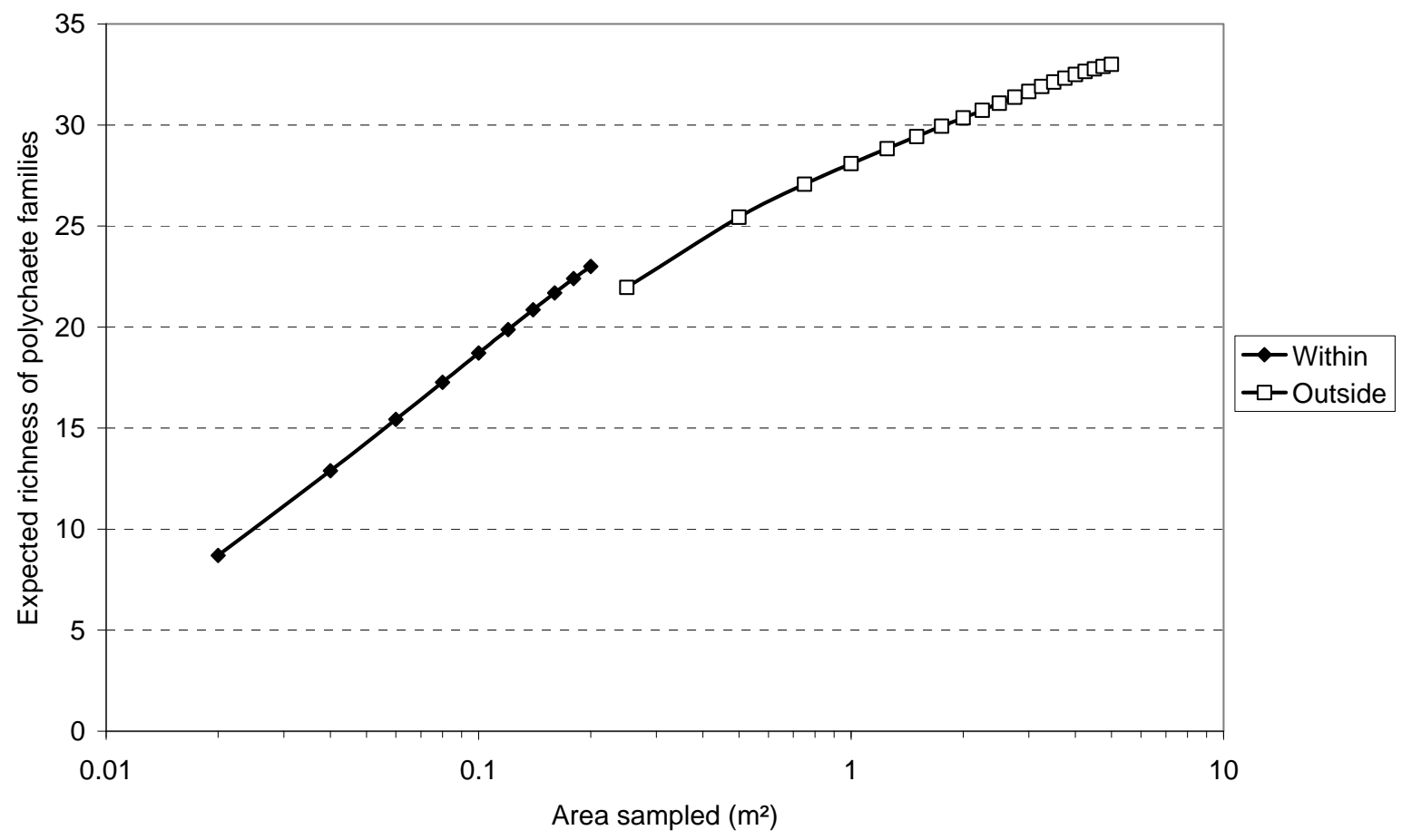

Figure 5

Figure 5: Sample-based rarefaction curves showing the expected number of polychaete families as a function of area sampled.

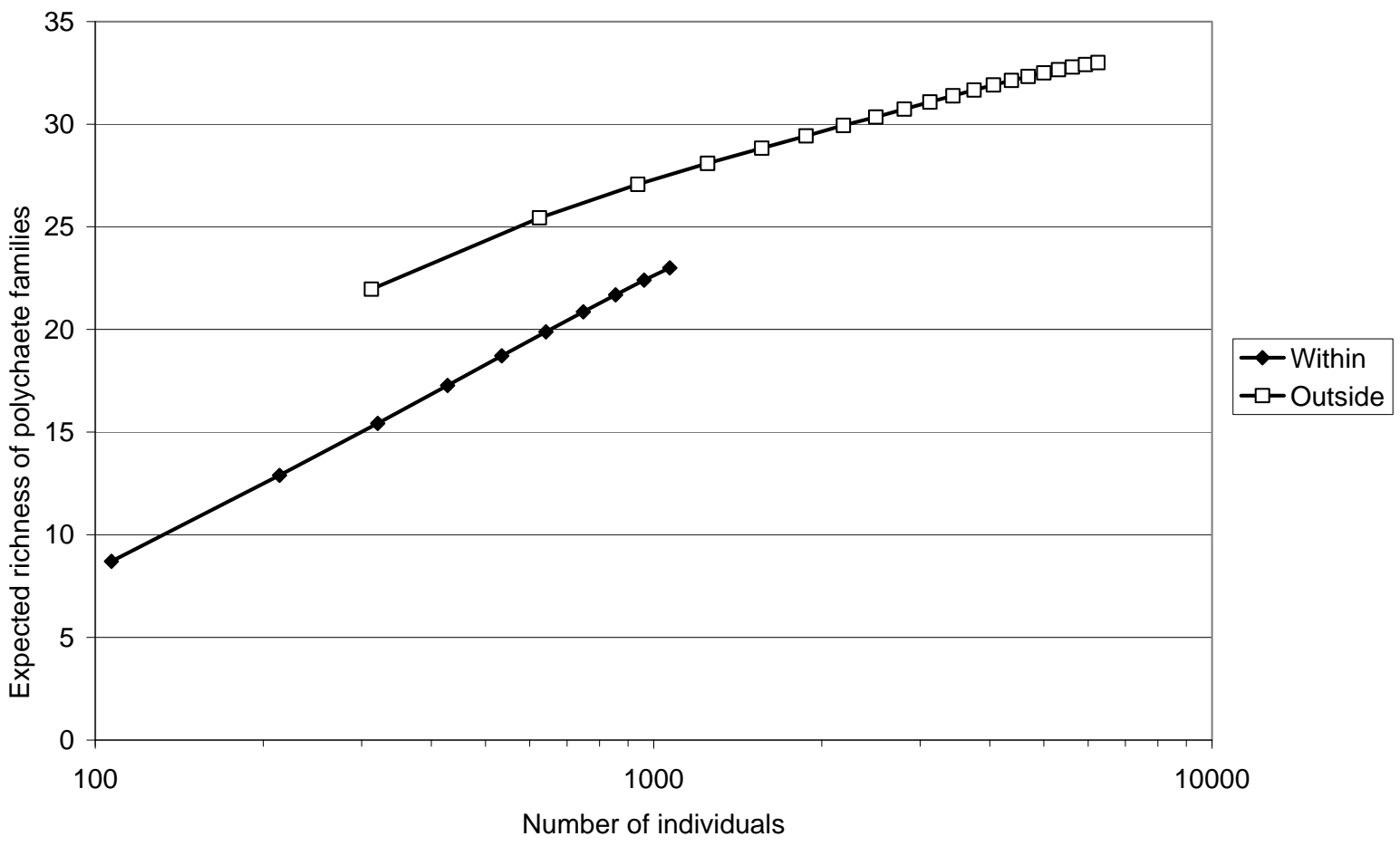

Figure 6: Sample-based rarefaction curves showing the expected number of polychaete families as a function of number of individuals. 


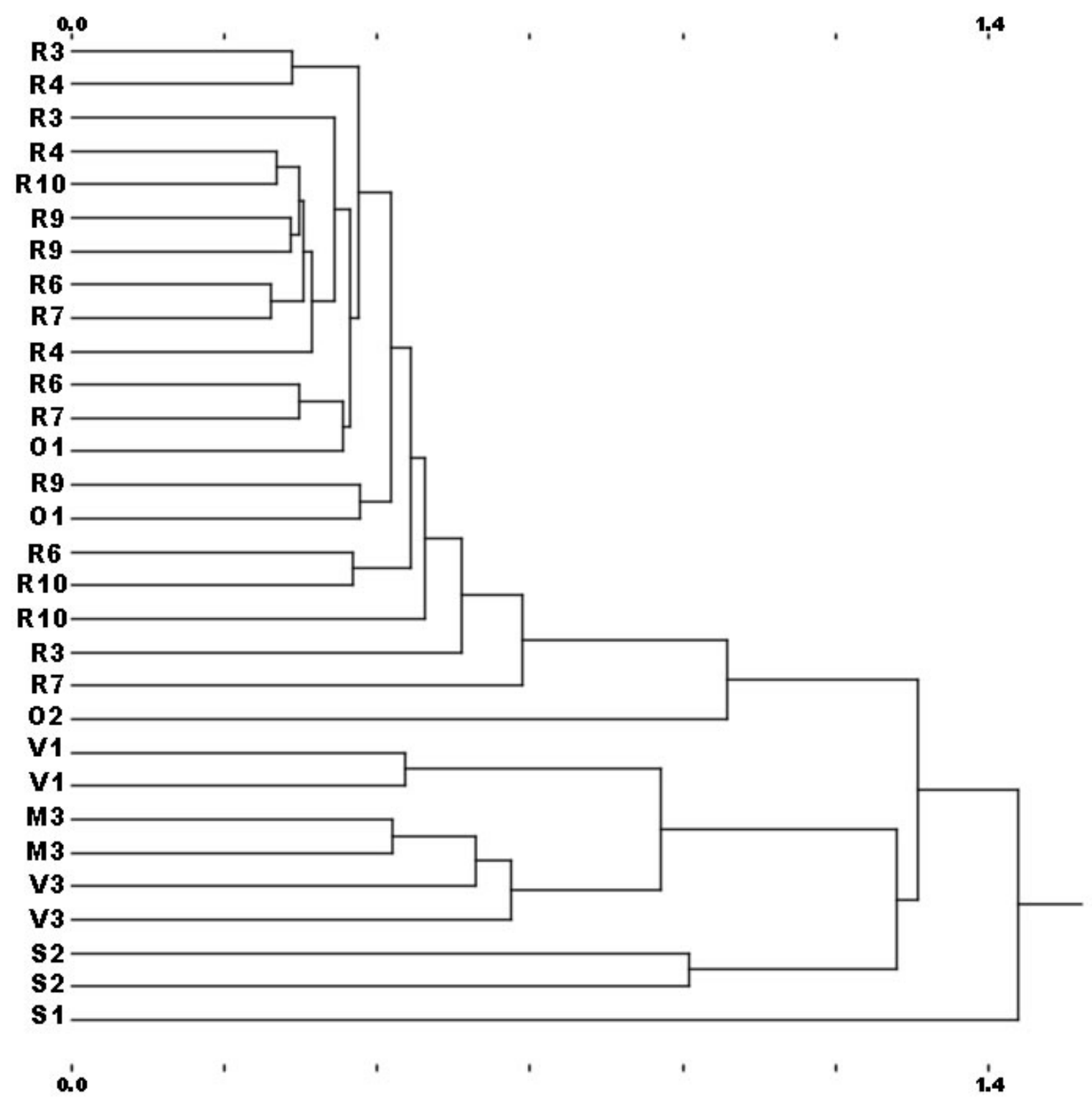

Figure 7

Figure 7: Dendrogram of a clustering analysis showing the Hellinger distance between samples according to taxonomic composition. 


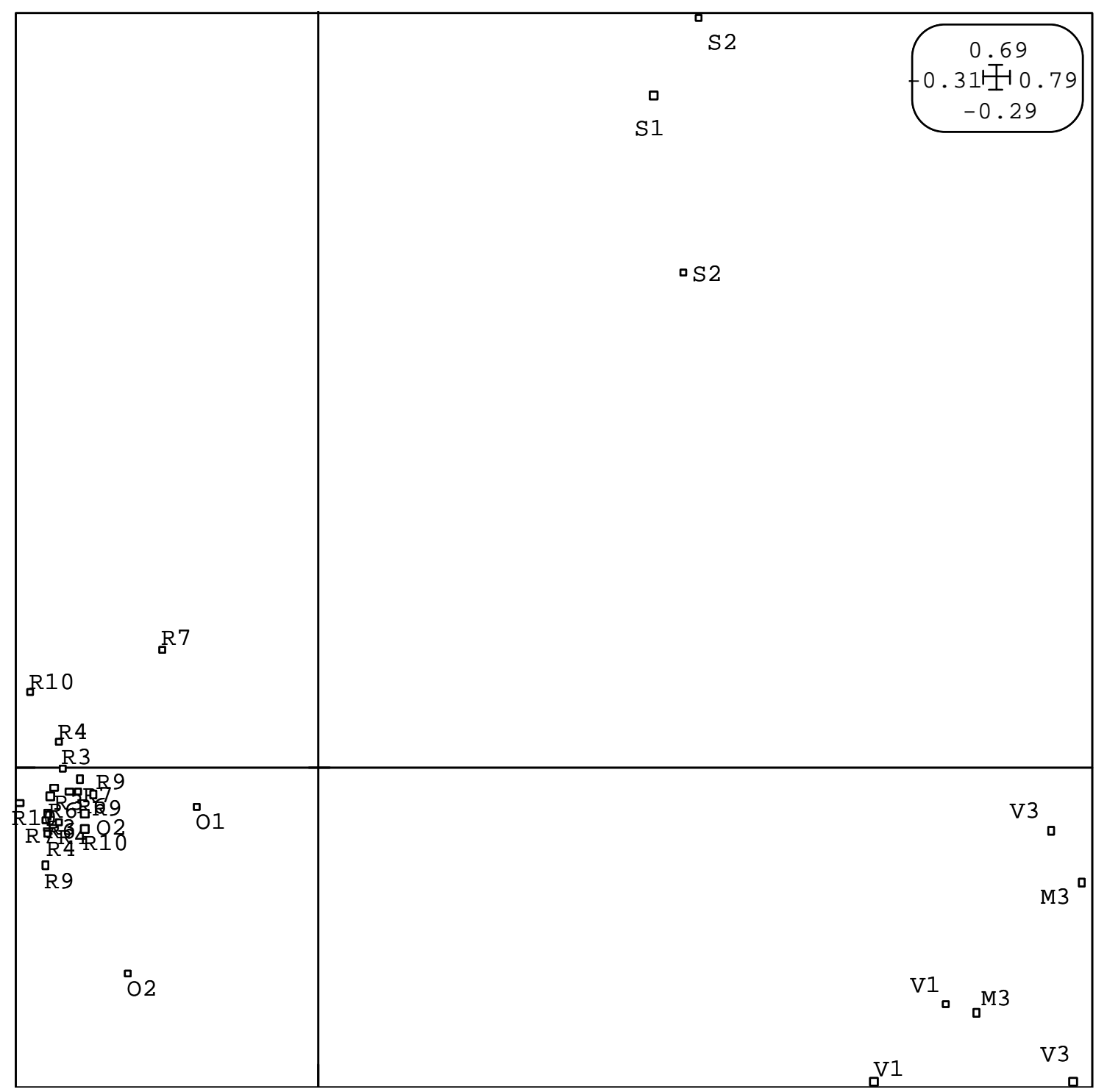

Figure 8

Figure 8: Ordination of samples in the two first axes of a principal component analysis, based on Hellinger distance computed on a sample $x$ taxa matrix. 


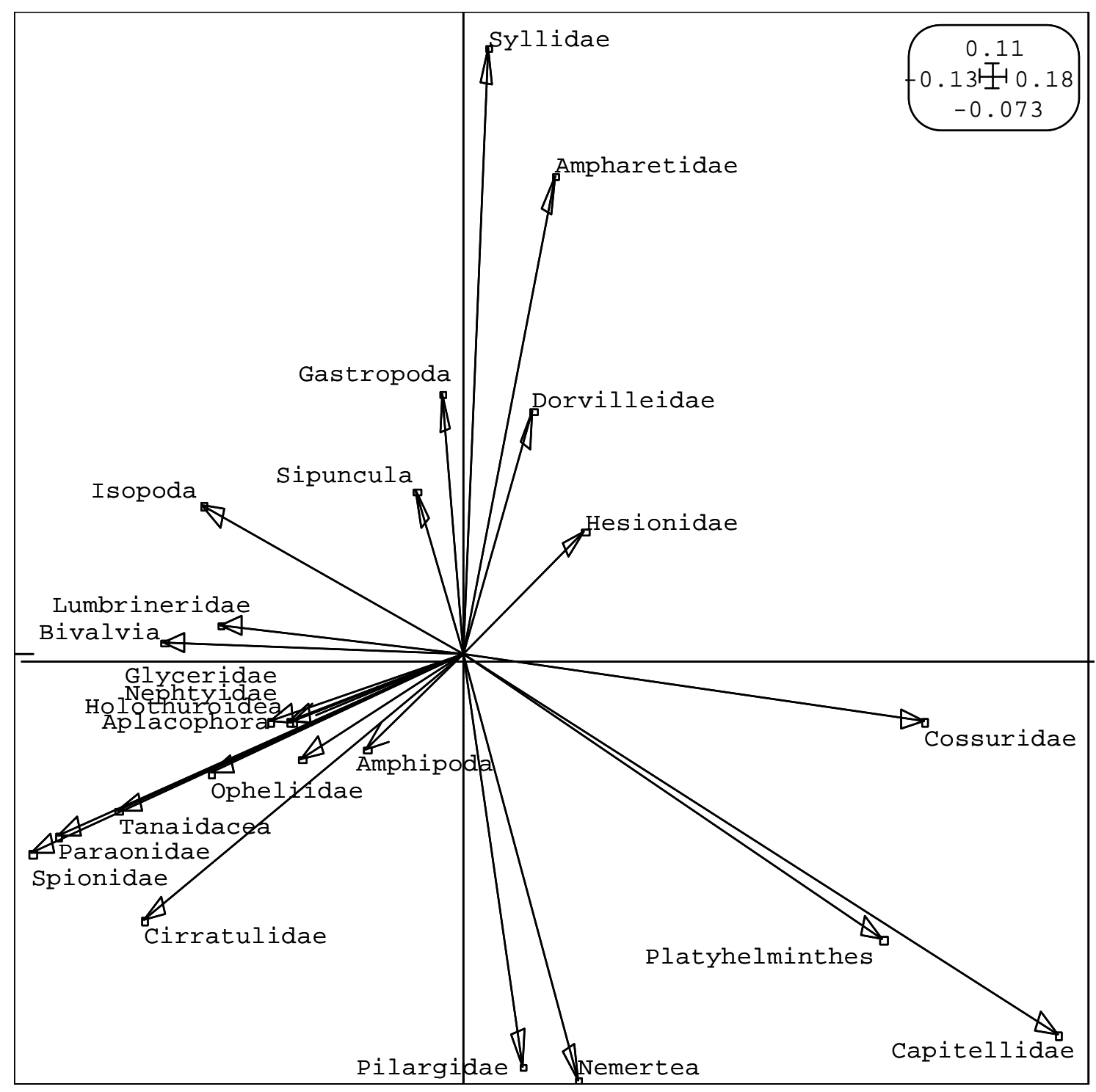

Figure 9

Figure 9: Ordination of taxa in the two first axes of a principal component analysis, based on Hellinger distance computed on a sample $x$ taxa matrix, only taxa contributed to more than $1 \%$ of either axes are shown. 